\title{
СІРИК АЮАМИАА
}

Аоктор габімітований, професор, аА’нкт кафеАри мітературознавства Інституту неофілології, Університет Марії Кюрі-Склодовської, Аюблін (Польща)

\section{SIRYK LIUDMYLA}

Dr. habil., a professor, adiunkt at the Department of Literary Studies of the Institute of Neophilology, Maria Curie-Skłodowska University, Lublin (Poland)

\section{Бібміографічний опис:}

Сірик, А. (2020) Антропологічна концепція мюдини в поезії київських неокласиків. Народна творчість та етнологія, 2 (384), 28-39.

Siryk, L. (2020) Anthropological Concept of the Person in the Poetry of Kyivan Neoclassics. Folk Art and Ethnology, 2 (384), 28-39.

\section{АНТРОПОЛОГІЧНА КОНЦЕПЦІЯ ЛЮДИНИ В ПОЕЗІЇ КИЇВСЬКИХ НЕОКЛАСИКІВ}

\begin{abstract}
Анотація / Abstract
У статті розглядається ідейно-семантичний зміст антропологічної концепції Аюдини, сформульованої у поезії мітературного угруповання київських неокласиків Миколи Зерова, Максима Рильського, Павла Филиповича, Михайла Арай-Хмари й Юрія Клена (спр. ім’я ОсвальА-ЕккарА БурігарАт) - чільних преАставників неокласицизму і проєвропейського напряму в українській мітературі XX ст. Питання досліАжено на матеріалі творчості періоду 1914-1934-х років. З’ясовано, що концепція грунтується на таких категоріях, як калокогатія (моральна і фізична досконалість, єАність прекрасного і доброго), істина, Аюбов, мудрість, шляхетність, працьовитість, стоїцизм, пізнання (себе і світу), мужність, самовдосконалення, гармонія, свобода, суспільна активність, солідарність, діалог, співпраця, творчість, патріотизм, щирість, урівноваженість, поміркованість, спокій, радість, традиція, право й обов'язок. Ці позитивно конотовані категорії визначають передумову щастя АюАини. У розглянутій моделі промується антропоцентричний характер культури з приматом імперативу моральності й гуманізму. Концепція висуває переА Аюдиною високі вимоги і водночас апелює до справеАливого суспільного маду, де вшановуються права на життя, свободу і гіАність, а також демократичні права. ІАейно-аксіологічний зміст концепції був запереченням раАянського тоталітарного режиму й одночасно сміливим викликом проти його антигуманізму, теорії «гвинтиків» і масовізму ${ }^{*}$.

Ключові слова: київські неокласики, цюдина, антропологічна концепція, поезія, калокогатія, гуманізм, мюбов, стоїцизм, моральність, гармонія, Аіалог, спільнота, традиція.

Ideological and semantic content of the anthropological concept of the person is considered in the article. This conception has been formulated in the poetry of literary group of Kyivan neoclassics Mykola Zerov, Maksym Rylskyi, Pavlo Fylypovych, Mykhailo Drai-Khmara and Yuriy Klen (his real name is Oswald-Eckard Burghardt) as the leading representatives of neoclassicism and European trend in the Ukrainian literature of the 20th century. The issue is investigated after the materials of the works of the period of 1914-1934. It is ascertained that the concept is based on such categories

* Під поняттям «масовім» авторка статті розуміє світогляАно-політичну тенденцію, у якій пріоритетом визнано АюАську масу, а не Аюдину. Це поняття має негативну конотацію.
\end{abstract}


as kalokagathos (moral and physical perfection, unity of the beautiful and good), truth, love, wisdom, nobleness, assiduity, stoicism, cognition (of myself and the world), courage, self-completion, harmony, freedom, social activity, solidarity, dialogue, collaboration, creation, patriotism, sincerity, steadiness, temperance, composure, gladness, tradition, right and duty. These positively connotated categories are used to determine the premise of the person's happiness. Anthropocentric nature of the culture with the primacy of imperative of morality and humanism is promoted in the considered model. High demands are brought forward the person by the conception. At the same time, it appeals to the impartial social order, where the person's rights for life, freedom and dignity and also democratic rights are esteemed. Ideological and axiological content of the concept has been the negation of the Soviet totalitarian regime and at the same time the courageous call against its antihumanism, the theory of small screws and mass character.

Keywords: Kyivan neoclassics, a person, anthropological concept, poetry, kalokagathos, humanism, love, stoicism, morality, harmony, dialogue, community, tradition.

В умовах радянської Аійсності 1920-1930х років, коли влада всілякими способами намагалася утвердити комуністичну тенденцію масовізму і менінську доктрину «гвинтиків», київські неокмасики возвеличували ююАину, намагалися донести до свідомості суспікьства їі беззаперечну цінність. Вони констатували право особистості на свободу і гіАне життя. Отже, виступали проти іАеології комуністичної влаАи, зокрема, пропаганди Аержавоцентричної культури. В обставинах раАянського режиму це була надто смілива і небезпечна позиція. Керуючись аксіологією сереАземноморської культурної й української національних традицій, неокласики конструюють антропологічну концепцію $ю$ юни, яка визнає і промує антропоцентричний характер культури з акцентом на моральність і гуманізм. З’ясування кмючових категорій цієї моделі ставить переА досліАником завдання визначити погАяАИ поетів на іАентичність АюАини у різних вимірах їі життя (Ауховному, матеріальному, суспільному, приватному) і в контексті іАеї про АюАське щастя. Об’єктом дослідження $є$ поезія ${ }^{1}$ знаного в українській мітературі «грона п’ятірного», тобто М. Рицьського, М. Зерова, П. Филиповича, М. Арай-Хмари, Юрія Клена - письменників, перекладачів, мітературознавців, чільних преАставників неокласицизму і проєвропейського напряму в українській мітературі XX ст.

Антропологічні пріоритети київських неокласиків формувалися піА впливом таких аксіологічних чинників, як: 1) філософія елмініз-

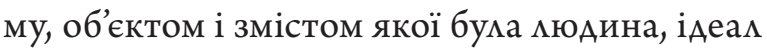

віцьної особистості, активної у суспільній і внутрішній сферах, що перебуває в гармонії 3 природою; 2) думка епохи Ренесансу, яка проголошувала іАею формування внутрішньовікьного індивіАуума, свіАомого власної автономії й гіАності; 3) українська націонамьна і родинна традиції, в основі яких - засаАи християнства, гуманізму, універсалізму і патріотизму. Із цих Ажерел митці черпали і творчо переосмислювали у поезії ці «вічні» образи, мотиви і сюжети.

Неокласики вважали, що апологія античності, зокрема емлінізму, мала раціональний сенс і виховне значення. У Стародавній Греції убачалося гуманітарним все, що стосується АюАини, а піА гуманним розумілися

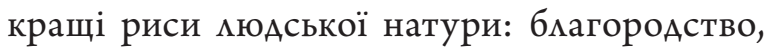
моральність, милосерАя, співчуття, висока культура повеАінки і кюАських взаємин. А я греків краса і моральність тотожні, морацьне не віАокремлювалося віА прекрасного. ПреАметом осмислення головних напрямів емлінської фімософії було щастя мюАини, яке, на Аумку мислителів, залежало віА способу їі життя й повеАінки. В культурі Елмади центром бума АюАина. Концепція АюАського щастя (основна ідея елмінізму) зумовлювалася взаємозалежними чинниками: культурою і мовцювала світський і антропоцентричний характер кумьтури, їі першочерговий інтерес

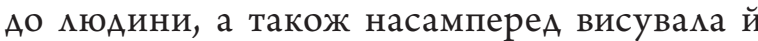
утверджувала тип духовно вільної особистості. Цю теорію застосовують неокмасики, піАкреслюючи значення свободи Ауху. Це був виклик теорії комунізму, яка трактува- 
ма мюАину мише як частину маси. ВіАомо, що раАянській вмаАі потрібна була мюАина покірна і безвімьна, яка бездумно виконує вказівки партії, словом - зі свідомістю раба. Усупереч цим тенденціям поети оспівувами мюАину, за посереАництвом якої реалізується іАеац краси емлінського зразка, ототожнений $з$ калокогатією. Трактують цей ілеал як абсомют морамьних цінностей. Вони визнають кумьт Гомера («Як ОАіссей, натоммений блуканням» М. Римьського; цикм «Мотиви ОАіссеї» М. Зерова; «Шияхами ОАіссея Ю Юрія Клена), характерний Аля кмасичної мітератури Аругої половини XVIII ст. Найвиразнішим прикладом іАеалу краси вважають античну Навсікаю: «Ясна, зцімюща, мов жива роса, / Рожевим сплеском Ециінського моря / Йому сміється радісна Краса» (М. Зеров «Навсікая»). Аіричний герой поетичного твору М. Римьського плекає наАію на особисте щастя: «піА безтурботний шемест / мене розбудить ніжна Навсікая, / Струнка Аочка феацького царя». Поети формулюють концепцію «святої Краси» (з вемикої мітери), уважаючи, що

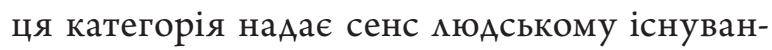
ню. У творах розгортається рефмексія про суспікьну ромь естетичного іАеалу у взаємодії з етосом і раціональним мисленням: «Сходять зерна наук / В гімнах ясній красі» (П. Фимипович «ВсюАи міта орем»). А в поемі М. Римьського «Чумаки», зокрема у пісні першій піА назвою «Автор міркує про мистецтво», піАкреслюється конструктивна роль

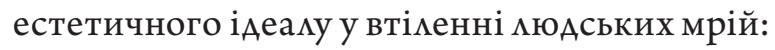

Краса і Аумка, Аві сестри-близнята, Аавно на морі цюАському пиивми. $<\ldots>$

\section{Так от бімі авері}

Краса в минуме вміє оАчинять

I в буауче ${ }^{3}$. СереА шамених прерій

I в тунарі, Ае сивіє біАний мох,

Нам світить Гейне, Тютчев, Архілох.

$[10$, c. 197$]$.

3 філософських теорій Стародавньої Греції неок асики сповідують апомлонівське (раціонамьне) начало, спрямоване на впоряАкування мюАського Ауху і суспімьства «служимо вмаАиці Апомиону» (М. Зеров «Lucrosa»), а також проголошують іАею траАиційного стоїцизму. «Аерзайте, мебеAi: 3 невомі, 3 небуття / веде вас у світи ясне сузір'я $\Lambda$ іри / Ае пінить океан кипучого життя», - закмикав М. Арай-Хмара в сонеті « АебеАі» 3 АеАикацією «Присвячую своїм товаришам ».

IАеал краси неокмасики трактують не мише як концепт, аме й як морамьно-етичну проблему. Вважають, що вона зумовцена Авома чинниками: а) зовнішнім, тобто суспіцьно-політичним устроєм; б) внутрішнім, тобто негативними рисами мюАини (егоїмом, слабодухістю, жорстокістю тощо). ЗгіАно з їнім переконанням, зовнішня врода

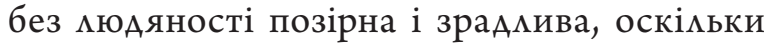
позбавлена Ауховної цінності й сакрамьності. Цю Аумку ілюструє інтерпретація бібмійного образу Самомеї ${ }^{4}$ (Аоньки ІродіаАи) в оАнойменних сонетах «Самомея» М. Зерова (1922 р.) і П. Фимиповича (Аата написання Аругого твору невіАома). Попри індивіАуамьне зображення, кожен із митців піАкреслює нерозсуаливість цієї героїні. ЗгіАно 3 першоджерелом, у Стародавньому Римі було страчено пророка Іоанна Хрестителя за дорученням юної царівни Самомеї, яка послухала намови своєї матері Іродіали. Ім'я пророка у вищезгадуваних сонетах звучить - Йоканаан. П. Фимипович зосереАив увагу на аморамьності царського Авору. Ця риса увиразнюється через контраст: 3 оАного боку, захопмення публіки танком вроАмивої Самомеї, а з Аругого, - байдужість Ао АюАського життя і жорстокість. Поет засуАжує «сліпу жагу» прислужитися цареві, щоб зміцнити свою позицію. Він констатує про безмежну жорстокість ІродіаАи: «Ти спопемить могла б життя народу, / Ти засмутима 6 соняшну блакить!». ОАнак умовний спосіб Аієслів не може цього зробити, позаяк ій протистоїть гуманізм і морамь, виражені через учення Іоанна Хрестителя і його послідовників. Натомість М. Зеров, окрім 
осуАу змочину Самомеї, шукає його причини. Його цікавить не мише вчинок Іродіади, яка, возненавидівши Божого пророка, штовхнума свою Аитину на смертельний змочин. На Аумку поета, головні причини цього вчинку кореняться в політиці імперської влаАи, яка не визнає $ю$ юських прав і етичних засаА, що руками інших виносить смертні вироки. У поетичній інтерпретації Саломея $є$ проАуктом виховання й оАночасно маріонеткою влаАи Риму:

I Саломея!.. Ще Аитя (Аитя!),

А п'є страшне, отруєне пиття

I тільки меч та помсту накмикає.

М. Зеров характеризує героїню як незріку особу, несвідоме «Аитя». Можмиво, поет віАштовхувався віА Аумки Аавньогрецького філософа Сократа, що змо виникає з невігластва, неосвіченості. Автор намагається певною мірою реабілітувати Саломею, хоча не виправдовує їі злочину. Передусім, він безапемяційно засуджує його причину, констатуючи, що тоталітаризм є насліАком аморальності.

Отже, через призму антиномії образів, 3 оАного боку, морацьно «чистої Навсікаї» (М. Зеров), а з Аругого, - спмямованих жахмивим змочином Іродіади і Самомеї, увиразнюється цінність елмінського ідеалу краси, тобто поєАнання етичного начала 3 естетичним.

У поезії неокласиків сереА елементів античного і водночас біблійного походження виокремлюється мотив подорожі. У поетичній інтерпретації митців він має різні значення, а саме: а) дорога в невідоме, яким $\epsilon$ наше життя; б) невпинний пошук істини і щастя, внутрішньої та суспільної гармонії, мудрості, правди; в) мандрівка, трактована як спосіб пізнання світу, самовдосконалення, відновлення сил на нове життя і на боротьбу зі злом. НаприкмаА, у сонеті Юрія Клена «Сковорода» (1928) «прекрасний шлях п подорожі українського фінософа символізує зразок Аля насліАування з метою самовдосконалення ${ }^{5}$ :
Оці мандрівки дальні та безкраї,

I, може, іншого шияху немає,

Щоб з хаосу Ауші створити світ.

Через мотив подорожі сформульовано цінність неухимьного пошуку свого місця У світі й сенсу АюАського життя. У контексті цього мотиву П. Филипович - усліА за Ернестом Хемінгуеєм - у вірші-переспі-

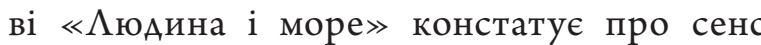
боротьби 3 життєвими труднощами та небезпеками. Пояснюючи кінцеву мету пошуку у вірші «НаАхмарний вітер полетів», поет преАставляє красу як конструктивний чинник і джерело оптимізму. Тому закликає:

Аивись на Аіл, на небеса І вчись прекрасного спокою Колись зійде і наА тобою Така врочистая краса.

У багатьох творах М. Римьського мотив подорожі означає шанс на реалізацію мріі

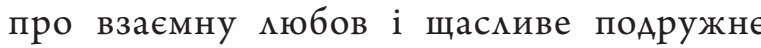
життя. Поруч із цим функціонує символічний мотив руки. ОбиАва виконують концептуальну роль. Приміром, у вірші «Згаси у серці змо!», зкученн я рук Аає перспективу на створення «нерукотворного», тобто Ауховного храму:

Аай руку - і ходім глибокими шляхами У храмі вічному схимить своє чоло, Заплакать радісно в нерукотворнім храмі.

Мотив подорожі в поемі-епопеї Юрія Клена «Попік імперій» символізує почуття громаАянського обов'язку - внутрішню потребу йти в концтабори («я в нетрі йшов», «на півдорозі Аанте заблукав»), щоб виявити і переказати світу трагеАію, спричинену тоталітаризмом раАянської і фашистської імперій. Отже, різні семантичні грані мотиву подорожі свідчать, що митці заохочують Ао суспільної і духовної активності, яка $\epsilon$ оАнією зі засаА естетико-світоглядної програми неокиасицизму. 
Головна риса світогляду неокмасиків полягає в антропоцентризмі, піА яким розуміємо філософію з наступними пріоритетами: а) визнає категорію імперативу центру, в якому перебуває мюдина; б) виявцяє опозицію до філософії утилітаризму; в) пропагує іАею золотої сереАини та проголошує іАею гіАності АюАини. Поети намагаються посАіАовно утверАжувати Аумку про АюАину як найважмивішу і виняткову цінність на землі. ОАним із багатьох прикладів $\in$ фрагмент вірша М. Римьського «Урожай»:

І в кожнім колосі тяжкім

Весняне сонце й майський грім,

I Аітній Аощ, і ночі сині -

І все це віААано АюАИні.

У конструюванні антропологічної моделі АюАини митці звертаються до філософської Аумки українського гуманіста, поета і фінософа-містика Григорія Сковороди (17221794). Його творчість $є$ квінтесенцією української бароково-просвітницької культури XVII-XVIII ст. Г. Сковорода, як і мислителі античності, сформулював власну концепцію щастя АюАини - синтезував гуманістичні засади, пропаговані елмінізмом і християнством. Уйого фінософських Аіалогах і трактатах біблейська проблематика переплітається з ідеями платонізму і стоїцизму; своєю чергою, у засаАах християнської етики беруть початок різні шляхи утверАження стрижневих морацьних вимірів цюАської особистості. Основними в теорії філософа є такі категорії, як пізнання світу, мудрість, серце, мюдина,

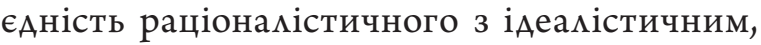
самопізнання, пов'язане з елмінською ідеєю самовдосконалення. Цей факт свіАчить про тяглість європейської гуманістичної традиції у вітчизняній мітературі. Не випадково філософія і творчість цього мислителя

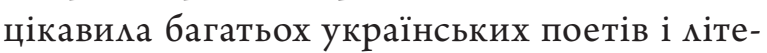
ратурознавців XX ст., зокрема, київських неокиасиків. Аля них поет-філософ був зразком до наслідування: «і я помандрую, як Сковорода» (М.Арай-Хмара «Розмютувався мютий надаремно»). Цю Аекмарацію пояснює Юрій КАен у вірші «Сковорода»: «Іти у сніг і вітер, в дощ і хугу / I мудрості вином розвести тугу / Бо, може, це нам вічний заповіт». ПіАкреслюючи доброчинне поширення його науки, міричний герой неокмасиків висловлює радість, що постійно «широким шляхом йде Сковорода» (П. Филипович «Залізний закмик»). М. Римьський у вірші «Китаїв» писав: «з палицею пікігрима / У нові села й городи / Прямує тінь неутолима / Григорія Сковороди». Проте, як слушно зауважили сучасні дослідники ${ }^{6}$, поети творчо використовують Аумку Г. Сковороди Аля самоусвідомлення і формулювання своєі позиції.

У контексті обговорюваної моделі глибоке символічне значення в поезії неокмасиків мають образи «бАжоли» і «серця», характерні також Аля творчості Г. Сковороди. Ао речі, ці мотиви зустрічаються в Аав-

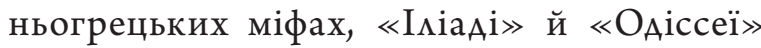

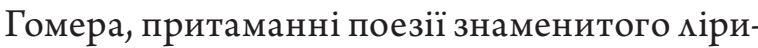
ка Піндара ${ }^{7}$, а їх використання наступними поколіннями письменників $\epsilon$ свідченням традиційного функціонування у класичній мітературі «вічних» образів. ЗгіАно з $і$ ітературною траАицією, бажола символізує працьовитість, упоряАкований суспікьний $а$ А, гармонію, співпрацю, єАність. Цей образ у вірші М. Римьського «Опівані» є алегорією творчої мюАини, яка, інтегруючись у спільноту, працює Аля суспільного добра і в цій Аіяльності самостверАжується:

Це ти гудеш роями бАжіл брунатних, $<\ldots>$

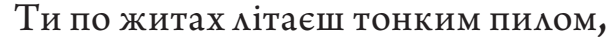
ЗапліАнюючи теплі колоски, -

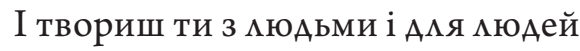
Нові міста, ти арки ажурові НаА синіми провамлями будуєш!

ЗгіАно з поетичною рефмексією, щоб утіАити мрії, задовольнити «серце, оповите снами», треба бути працьовитим, «мов та бАжола» (М. Арай-Хмара «Наставика шов- 
кових кросен»). Цей образ також є символом «золотої» краси і Ажерела ралості, яким $\epsilon \ll с п і в$ бАжоли» (М. Арай-Хмара «Мені сниться $\gg)$.

Образ серця $є$ уособленням таких конструктивних начац, як У вірші П. Фимиповича «Небо осіннє, мов квітка, марніє» серце порівнюється 3 «маленьким буАинком на неосяжній хомоАній земмі», місцем безпечним, затишним i приємним. Образ серця оспівано у творіпереспіві «Снігова королева» в контексті антиноміï «добро - змо». Поет спирається на фабулу відомої казки Г.-Х. Андерсена про Аівчинку ГерАу, яка врятуваца свого молодшого брата Кая віА невомі Аушевного хомоду. Героїня твору - символ віАваги в боротьбі з небезпеками світу як матеріального (сніг, мороз, міА, завірюха), так і духовного (байдужість, піАступність, Утимітаризм). Симою мюбові вона зуміла розтопити поневолене холодом байдужості серце брата. Український поет закмикає: «Маєте серце із криги, - / Треба ж його розтопить!». В іншому його творі мунає застереження переА небезпекою віАсутності серце чуже хомоне, / Умира, не може мюбить» (П. Фимипович «На потаку камінним кригам»). Аіричний герой М. Римьського у творі «Згаси у серці змо!» закмикає Ао змагоАи і радості, а М. Арай-Хмара Аекларує: «з серця в серце я намхю пісень» (М. Арай-Хмара «Розмютувався мютий надаремно»). В анамізованій поезії категорія серця виконує ромь комунікативного і гуманізуючого чинника. 3 метою сакрамізації позитивно конотованих образів поети вживають у якісній функції епітет «золотий», який у різних контекстах означає «тривкий», «Аобрий», «люблячий », «гарний». Цей хуАожній засіб використано щодо характеристики АюАини - «золоте серце бабусеньки» (М. АрайХмара «Аист до Оксани»), хміба і роботящих рук землероба - «ціп сторукий / Змолотить золоті, обтяжені снопи» (М. Римьський «Пам'яті АяАька мого Кузьми Чуприни»), оточуючого світу - «зорі золоті» (М. АрайХмара «Симфонія»).

Неокмасики, осмислюючи ПрироАу мюАини в онтологічному аспекті, вбачають у ній безмежний потенціал: «АюАино, хто зміряв Ауші німі глибини?» (П. Фимипович «АюАина і море»); «збагнути серце хоче таємницю таємниць» (М. Арай-Хмара «На смерканні»); «Спізнай, яка у цімім гмибина! (М. Римьський «Тріпоче сокіл, сріблом потемнімим»); «зору глибина / Тужмиві оАкидала тіні» (М. Римьський «М. Н.

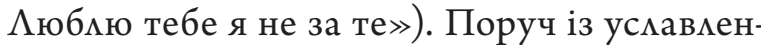
ням віАомих особистостей (митців, учених, народних героїв), поети зАебімьшого оспівують звичайних безіменних мюдей, зокрема, матір, сина, хиібороба, косаря - простих працьовитих труАівників, у боротьбі з життєвими випробуваннями мюАяних і нескорених, які стають зразками Аля насліАування й об'єктами сакрамізації.

Важмивою скмадовою АосліАжуваної модемі є категорія мюбові, що реалізується за посереАництвом АюАини і в ЗгіАно зі світогцяАом поетів, справжнім щастям наАімити мюАину може тімьки Аруга мюАина, оскільки «мовчать і місяць, і буАови, / Панує ніч, і стежим ми самі, / Як в нас палають закмики мюбови» (П. Фимипович «Синіє сніг і стемяться розмови»). У парубкові зроджується наАія на щастя, коли він спілкується 3 Аівчиною, яка «ясна, як саА, i радісна, як сміх» (М. Римьський «У тепмі Ані збирання винограду»). Поети наАають

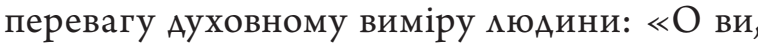
чуття самовіАдані й прості, / Як красите ви біАний

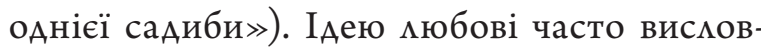
Аюють крізь призму жіночих образів: матері, коханої, приятемьки, сестри тощо. «Я чую тімьки гомос мимий, / Я бачу світ, бо в світі ти» (П. Фимипович «Коми метять, як сиві

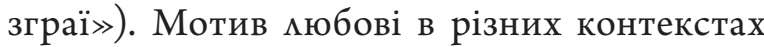
проникає багато творів, зокрема «Яблука Аоспі $и$ », «Коми втікаючи оА пимьної роботи», «Чумаки» М. Римьського; «Аист Ао Оксани», «Маленькій Оксані» М. Арай- 
Хмари; «Коли почую твій співучий голос» П. Филиповича. Аргументуючи Аумку, що $\Lambda$ юбов надає сенс і радість ванню, поети використовують приклаАи 3 власного АосвіАу й «осучаснюють» жіночі «вічні образи», почерпнуті з античності, Біблії, мітератури Нового часу. Вони зберігають первинну символіку цих образів, інтегруючи її у контекст існуючої реальності і в омріяний образ земної жінки-сучасниці. Об'єктом глорифікації є символічний образ Прекрасної Аами, ілюстрацією чого $є$ вірш М. Рицьського «Не ясноокий образ Беатріче» та російськомовні вірші Юрія Клена «Я шём с мечтой о Беатриче» i «Быть может, жаАно мовишь крики птички». В останньому виражено надію на кохання i щастя:

И может быть, тебя, как Беатриче, КогАа-нибудь я встречу на кугу, Останусь в заколдованном кругу, Чтобы скучайной песней возвеличить $[7$, c. 338].

Окрім зазначеного, елементом концепції $\Lambda$ юАини є $\dddot{̈ і ̈ ~ п р и ч е т н і с т ь ~ А О ~ \Lambda ю А с ь к о і ̈ ~ с п і \Lambda ь-~}$ ноти, зокрема родини, Ае реалізуються категорія Аюбові й морально-етичні засади національної та універсальної (середземноморської) традицій. СтверАжується, що мюАина цілковито самовиражається мише в спільноті. Аргументацію цих погляАів розгорнуто крізь образи персонажів на тлі «маної вітчизни», уособленням якої є ріАний Аім, сільська спіньнота, природа. Зі сфери суспікьних віАносин поети видобувають факти, які свіАчать про зразки моральності, гуманізму, гармонії. Так, у колі стосунків «люАина-родина» зображено образ щасливої домівки, що творять особи різного віку: АіАусь, бабуся, мати, батько, син, донька, онуки, правнуки. У цій оселі панують мюбов, гармонія, спокій, раАість і безпека, пахне «медом і пашнею» (М. Арай-Хмара «АiА»), а веселі діти граються біля «ласкавої мами» (М. Римьський «Коні»). Іменні персонажі та $і$ іричний герой подані як носії вічних і визначальних рис доброї, муарої, совісної і працьовитої ююАини. Тему родини і кохання ${ }^{8}$ найповніше розгорнуто у творчості М. Римьського («Весною ми їзАили в поле», «ОА голосу пашить і віє», «Аитинство», «Косовиця»,

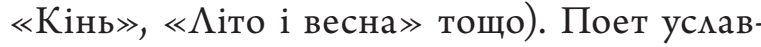
$\Lambda ю є$ органічну спільноту роду. Аля кращого розуміння їі цінності, у вірші «Тріпоче сокір, сріблом потемніким» він порівнює ріА 3 високим розногим деревом. Застосовуючи художній паралелізм, заохочує вскухатися у звуки соків, які переходять крізь плоАюче та високе Аерево. «Спізнай, яка у цілім глибина!», - закмикає він, а також констатує про цінність спі ььної праці у вірші «Урожай»:

ҺюАини труА - мільйони рук, Мільйони серць! В єаиний звук Мільйони струн народних зАиті У цій пшениці, в цьому житі!

На переконання М. Римьського, справеАмивий подік ії результатів, зАатність ділитися 3 іншими свіАчить про моральний етос суспільства. Промовистим виразом гуманізму народної традиції $є$ взаємне обдаровування хлібом - вираз пошани. У творі «Новий хліб» образ «всесимьного хміба» має матеріальний і Ауховний вимір: «життєАайні аромати», які розносяться по хатах, наповнюють Аюдей радістю. Усвідомлення його незамінної цінності приходить тоАі, коли хліба нема, коли панує голоА.

Прикметно, що поети часто зображують мюдину на тмі буденного життя. Вони оспівують звичайні справи, які внаслідок своєі щоденності стають непомітними. На думку митців, життя скмаАається з простих речей і не обов'язково має бути віАзначене великими подіями - вистачить виконання щоденного обов’язку, щоб це життя ушмяхетнити. Із хви-

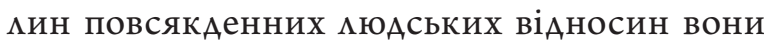
намагаються «видобувати» факти краси і Аобра («Косовиця», «ОА голосу пашить $\mathrm{i}$ віє», «Труди і Ані» М. Рильського; «Коли почую твій співучий голос», «Немов оту 3 пожовкцими Аистками» П. Филиповича 
тощо). Зображена у творах щоденність - це та, яку помічено і схопкено в миті переживання щастя, Аюбові, радості праці, єАності родини чи спільноти. Це ті, за влучною метафорою В. Моренця, «оази життя, які з вели-

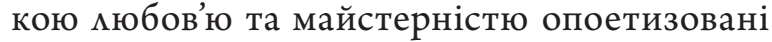
й автоматично переведені з плану конкретного часу в понадчасовий епічний план» ?

В обговорюваній творчості іманентно

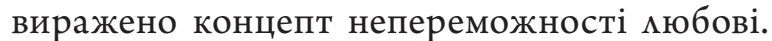
Його вагомою скмадовою $є$ образ жінки, який поети протиставляють смертоносній тоталітарній системі. Чітким прикладом $є$ вірш М. Римьського «М. Н. Аюблю тебе я не за те», Ае уславлено жіночу мюбов, мудрість і віААаність, аАже сила цих якостей зумовлює стоїцизм:

Hi! B час, коли юрба ішла,

І вкомо тебе кмекотіна,

I брудні славима Аіла

ПіА назвиськом святого Аіка, -

Ииш ти, самотна й мовчазна,

Як скеля, в західнім промінні Стояла, й зоруглибина

Тужииві одкидала тіні.

I непомітно я прийшов

У мохитовному тремтінні:

Тобі оАній моя Аюбов,

Тобі слова мої єАині.

Піднесені почуття викликає безмежна $\Lambda$ юбов і мужність матері, зображеної у поемі М. Арай-Хмари «Констанца». Прототипом цього образу є вбога жінка, яку царський урян заслав у Сибір за «змочин» іiі сина, котрий був учасником повстання моряків на броненосці «Потьомкін ${ }^{10}$, а згодом із товаришами втік за кордон та оселився в Румунії як політичний емігрант. Образи матері й сина безіменні - це вказує на типовий характер подій. Мати, «перейшовши тисячі митарств» і кілометрів, «на чужині, без язика» веде важкі розшуки, щоб побачитися 3 Аорогим сином. У реальності вона втекла із Сибіру і скористалася воєнною ситуацією, щоб перейти західний кордон Російської імперії (твір написано піА час Першої світової війни). Тільки мати зАатна на такий подвиг. НаАзвичайно зворушливими $є$ епізоА зустрічі після багаторічної розлуки та хвилина прощання з сином і його родиною.

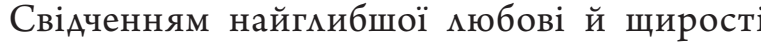
$є$ куплені за останні гроші подарунки Аля малих онуків. РаАість зустрічі й біль розмуки - усі ці хвилювання пронизані вистражАаною мрією і водночас гірким усвідомкенням, що зустріч може бути останньою. Мати мусить повернутися Аодому. Натомість ii син має залишитися на чужині. Вочевидь причиною їхньої трагеАії $€$ тоталітарна політика імперської влади.

Аля неокласиків, крім мюбові, важливою якістю характеру мюАини $є$ також сима волі. Так, у вірші М. Римьського « Аеся Українка» $[11$, т. 3] оспівано фізично кволу, але духовно міцну письменницю: «<...> справді хвора, - / А душа - немов океан». Вона «радістю в муках сіяла», зуміка йти назустріч бурям змивам, бути великою, як рать, змогла «жити в нещасті життям щасливим» $\mathrm{i}$ «муку творчістю перемагать». Мислення поета спирається на неокмасичну теорію сильної особистості. Це був кмич до ідеалу вільної і сильної духом Аюдини, а також закмик Ао траАиційного стоїцизму - риси, притаманної героям неокласиків ${ }^{11}$. Не випаАково у творі П. Филиповича «Чому невільникам Аумки про волю милі?» за мегкою іронією прочитується осуа слабодухості, песимізму, покірності, пасивності, фаталізму, інерції, наївності: «Раби розумні ми, тож поєАнать волім / Всі задуми свої із жеребом своїм, / I буде супокій, щаслива буде Аоля». Тому цілком виваженим є заклик Юрія Клена у вірші «Україна»: «Живи вогнем / В жару невгаснім / Свій гнів гартуй / I долю власну / 3 умамків куй». Усупереч нікчемному світу і сірій буденщині, міричний герой Аекмарує: «Я і ока не заплющу, / Буду пить не забуття - / Пить отруйну і зцікющу / РаАість мудрого життя» (П. Филипович «Ти поглянь - у темній чаші»). 
Щойно згадана сила волі тісно пов'язана 3 категорією свободи, яку митці осмислюють не мише в Ауховному, а й суспі ььно-політичному вимірі. Юрій Клен, обтяжений гірким Аосвідом неволі на засланні та в тюрмі, писав у поемі «Прокмяті роки»:

Але в тюрмі я, мов Аитя у школі, навчивсь кохати сонце і життя. Який чудовий перший день на волі, коли, черкнувшись грані небуття, ти знову чуєш спів женця у полі, мов він твоє вславцяє вороття!

Неокмасики, усвідомлюючи трагеАію України в умовах раАянської системи, проголошують думку про незалежність української держави. У багатьох творах віАстоюють іАею патріотизму і порушують пробкему громаАянської позиції. Проектують їх на різні ситуації нюАського життя: віА перебування в затишку «малої вітчизни» Ао ситуацій ув'язнення чи вироку смерті. Поети самі постійно були піА загрозою, яка наростала віА 1930 року. У березні 1931 року НКВА першим заарештувало М. Римьського і на шість місяців кинуло до в’язниці. Юрій Клен (тоді ще О. БургггарАт), німець за походженням, вирішив знайти порятунок у Німеччині. На прощання М. Зеров присвятив йому сонет «Karnos tes patridos», створений 1931 року (з грецьк. Kanvóç tç (ntf) yaíqç «Аим країни ріАної»), із циклу «Мотиви ОАіссеї», у якому підкреслив вірність патріотичному обов’язку, віААаність Україні. 3 відомих причин контакти неокмасиків обірвалися, але Ауховна єАність збереглася. ВіАповіААю на питання мідера неокмасиків можна вважати вірш Юрія Клена «Шияхами ОАіссея». У цьому творі бачимо, що заповіАь свого колеги 3 «грона п’ятірного» поет зберіг i намагався реацізувати. $\Lambda$ іричний герой його вірша закмикає Ао патріотизму:

Пам'ятай: в'ється Аим кучерявий 3-наА хат, зріє хліб, і червоні хитаються маки там, Ае ріАна на тебе чекає Ітака і занедбаний твій маєстат.
У поемі-епопеї «Попіц імперій» наратор репрезентує емігранта, прототипом якого $\epsilon$ сам Юрій Клен. Він визнає, що в «морі чужини» почуває себе невпевнено - як у «хиткому човні» $[7$, с. 319]. 3 теплом згадуючи «все пережите, Аацьнє і близьке», він не може позбутися ностальгії, знайти місце, Ае буде так, як «бумо удома», тобто в Україні. Образ української АркаАії не мише збуджує «голубі пожари мрій» і вириває 3 «чужини», а й викликає страждання, оскільки Батьківщина окупована ворогами, у «згарищах чорніє» $[7$, c. 319] і залишається недоступною.

В естетико-етичній системі антропологічної концепції мюАини неокласики піАкреслюють значення Аіалогу. Митці вважають, що він має конструктивний характер - творить «згоди Колос» (М. Зеров «Аіва») і Аопомагає побачити «наАію в інших» (М. Римьський «Шиях»). Образ, зображений у сонеті М. Римьского «У тепці Ані збирання винограАу» свідчить, що усміх і привітний погляА бУАять віАчуття радості існування, а в миті переживання щастя все стає красивим, навіть сіра курява Аороги («звився пиц, немов рожевий Аим»). Промовистим атрибутом іАеї Аіамогу $є$ мотив поєАнаних рук, який у творах символізує співаружність, солідарність і передумову втікення мрії про щастя. Ао речі, не випаАково в українській народній траАиції вираз «просити руки» означає пропозицію оАруження. ЗгіАно з поетичною рефмексією, без Аружньої руки ближнього АюАина відчуває самотність і стражАання. Гостроту Аушевного болю зворушмиво переАано в образі дитини-сироти, яка потребує «гарячої й мудрої руки» батька (М. Римьський «ВзабріА») чи каскавих рук матері (М. Арай-Хмара цикц «Мати»). У багатьох творах обговорюваний мотив символізує Ажерело сили Аля витримки піА час найважчих життєвих випробувань, у хвилину смерті:

I гіркоту цієї муки

Пики ми з повного віАра 
I мовчки поєАнавши руки,

Буми, як брат і як сестра.

(М. Арай-Хмара «Я помюбив тебе»).

За слушним тверАженням П. Филиповича, приязну руку Аопомоги може подати мише той, хто має «серце чуме» («Нема словам мічби»). Мотив поєАнаних рук багатогранно функціонує у його інтимній Аіриці ${ }^{12}$ :

Як Аоторкнеться Ао руки рука, Почую хвимі, теплі і невпинні, I кмичу раАість буйну і весняну, Не раз, не раз ще зашумить життя! («Немов оту з пожовкмими мистами»).

Мов Аитина невимовно радий

\section{Аоторкнусь Ао теплої руки.}

(«Це призначив тоскний, невблаганний»).

Твоя рука в моїй руці,

Спокійно і бадьоро минуть

У миисту Аалечінь Аумки.

(«Напівосінній дощ»).

\section{Руки загорімі і нескорі}

Подали напитися мені.

(«Не вино, не сон і не отруту»).

Формулюючи антропологічну концеПцію АюАини, неокмасики стверАжують органічну єАність АюАини з прироАою: «стомлені Ауші зливались / 3 живою Аушею землі» (М. Римьський «Весною ми їздили в поле»); «я з землею зрісся - не вирну» (М. Арай-Хмара «Мені сниться»); «І раАість, і рани / Аороги моєї / Спменись, як коріння у чорній земмі» (П. Фимипович «Як мистя торішнє»). П. Филипович оспівує благо «непорушної згоди» («Колосом стигне слово»), гармонії, яка характерна природі. Він закликає наслідувати цю рису і з почуттям обов'язку берегти світ фмори і фауни («САава весняній траві», «Шануй гніздо старого чорногуза»). У природі поет убачає життєву муарість:

Повітря, рослини, воАИ -

Вславцяють усі блакить,

УСі ПрихоАяТЬ АО ЗГоАИ

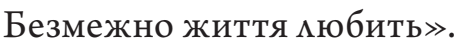

(«Не змато, миван і смирну»).

У віршах П. Филипович констатує, що «криниця вічної природи», як Ажерело віАродження - «стаєш магіАний, Аобрий» («Ямби»), енергії - «повітря п’ю радісний кемех / I очі п’яніють щомить» («Не смуги золотисті»), радості - «3 усіх рослин весемий Азвін» («Не тане Аень»), гармонії «серце земні гаряче б'ється в ніжних грудях твоїх («Хай на небі»), самоутверАження «Став чоловік наА чорною рілмею / Як небо горАий, симьний, як земля» («ВсюАи ореА

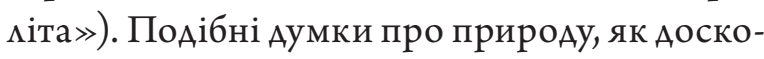
налий зразок Аля насліАування, пронизують творчість усіх неокмасиків. Особливої уваги вартує закмик у вірші Юрія Клена «Сковорода»:

Вбирати в себе вітер і простори, I $\Lambda$ iс, і $\Lambda$ ан, і небо неозоре.

Ауші кише співать: «Цвіти, цвіти!» Аж власний світ уній почне рости, В якому будуть теж сонця і зорі.

В уривку «Аіалог мюАини з землею» поеми «Попік імперій» Юрія Клена піАкреслено Авосторонній характер взаємозв'язку: 3 оАного боку, мюАина після трагеАій звертається саме Ао життєАайної «вічної землі», а $з$ Аругого, має обов'язок ії обробляти. «Ралом залізним зорай цілину запахущу, / Засів розкинь золотистий!» <...> Сину мій! Потом гарячим мене напої!» [7, с. 357], - закмикає автор.

Цікком свіАомо поети вхоАять У роль психологів, філософів, політологів і зображують АюАину в екзистенціальному, Ауховному, суспільно-політичному та природному виміpax. Митці намагаються відкрити перспективу, яка допоможе Аюдині збагнути сенс буття, обрати життєву фімософію, віАшукати своє місце у світі й бути щасливою.

У ході Аослідження з'ясовано, що антропомогічна концепція АюАини в поезії київських неокмасиків спирається на засади гуманіз- 
му і Аекларує антропоцентричний характер кумьтури з приматом імперативу морацьності й гуманізму. Ця концепція грунтується на таких категоріях, як камокогатія (морацьна і фізична Аосконалість, єАність прекрасного і Аоброго), істина, мюбов, свобода, шияхетність, муарість, гармонія, працьовитість, стоїцизм, пізнання (себе і світу), мужність, самовдосконалення, суспільна активність, сомідарність, Аіалог, співпраця, творчість, патріотизм, щирість, урівноваженість, поміркованість, спокій, раАість, традиція, право й обов'язок. Ці позитивно конотовані категорії становмять передумову щастя мюАини. Поети прогомошують іАею боротьби за щастя і закликають до наполегливої праці, аби зі щоденності видобувати радість і сенс життя. Кмючове значення вони наАають Ауховному світу АюАини, який вияв яється в гуманістичній позиції, в устремлінні Ао вищих цінностей - краси, Аобра, істини.

Зі змісту розглянутої модемі можна виокремити наступні концептуальні Аумки: а) життя і щастя мюАини зумовлені їі системою цінностей, характером, симою волі й Аіями; б) етос мюАини рятує світ віА змо-

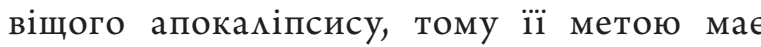
бути гуманізм, що є передумовою життя; в) у $ю$ юни $є$ права й обов'язки, тому вона мусить віАповіАати за свої учинки. У конструюванні концепції поети використовують Аавно минумі або характерні існуючій Аійсності факти історичної ваги. Черпають з філософії елмінізму, Ренесансу, спалщини Г. СковороАи, сереАземноморської кумьтури й української національної традиції, а також творчо переосмислюють «вічні» образи, мотиви і сюжети.

Концепція неокмасиків висуває переА ^юАиною високі вимоги. Вони помягають у тому, щоби в ім'я високих іАеамів боротися із самим собою і самовдосконалюватися. IАейно-тематичний зміст розглянутої моде $і$ протистоїть комуністичній теорії «гвинтиків» і масовізму, наАаючи примат гіАності та свободі кожної мюАської особи, примат рівноправності та морамьному етосу. Поети промують тип вільної Аухом АюАини, зАатної протистояти зму. Творячи візію суспікьного $а$ ау, у якому реалізується право кожної $\Lambda$ юинни на гіАне життя, вони поміщають їі в коло гуманістичних засаА.

\section{Примітки}

${ }^{1}$ Наведені у статті цитати з творів подано за виданнями: Рильський М. Зібрання творів у Авадцяти томах. Київ, 1983 [10; 11]; Зеров М. Твори в Авох томах. Поезії. Переклади. Київ, 1990 [6]; Филипович П. Поезії. Мюнхен, 1957 [14]; Арай-Хмара М. Вибране. Поезії та переклади. Київ, 1969 [4]; Юрій Киен (ОсвальА БургарАт). Вибране. Київ, 1991 [7]. При назвах цитованих творів указано імена авторів; номер сторінки подано при цитатах, зачерпнутих із творів, які нараховують понаА Аві сторінки.

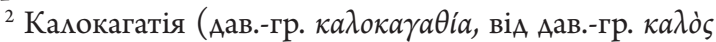

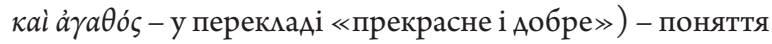
Аавньогрецької класичної естетики, що виражає ідеальне єАнання фізичної краси і духовної досконалості - як ідеал виховання мюдини. URL : https://uk.wikipedia. org/wiki/ Камокагатія. Аата звернення 12. 02. 2020 року.

${ }^{3}$ Видімення напівжирним шрифтом тут і дамі моє. A. C. [5].

${ }^{4}$ Пор.: Зварич В. Образ Саломеї у поезії неокцасиків

${ }^{5}$ Пор.: Астаф'єв О. Вірш Юрія Киена «Сковорода»: спроба прочитання [1, с. 4-7].
${ }^{6}$ «Неокласикам властивий цілком особливий тип творчої саморефлексії - він вельми Аалекий віА Аомінуючого в їхній Аобі, але близький до того типу творчої особистості, що визначає поета-мислителя, поета-фінософа як $\Lambda$ Бо, Ау Фу, Бгартрігарі чи Сковорода, надто ж у XX столітті». Соловей Е. Українська філософська мірика. [12, С. 185]. Також Аив.: Астаф’єв О. У пошуках світової гармонії (Григорій Сковорода і Юрій Клен: Аіамог через віки) [2].

${ }^{7}$ Як автор гімнів і майстер оди особливу славу зАобув Піндар (Pindarus, бл. 518-443 або 438 Ао н. е.). Ао нас Аійшио його 17 книг. Поет писав, що бАжоли «у крихітних груАях велетенським обертають Аухом» $(<\ldots>$ operosa parvos carmina fingo).

${ }^{8}$ Аив.: Стеценко О. [13].

${ }^{9}$ Пор.: Моренець В. Національні шияхи поетичного модерну першої половини XX ст. : Україна і Польща [8, c. 249].

10 Назва корабля віАсилає нас до історичної поАії червня 1905 року в Російській імперії, коли моряки військового корабля «Князь Потьомкін-Таврійський» Чорноморського фмоту виступими проти жорстокості 
офіцерів керівного складу. Відбулося перше в історії Російського фмоту збройне повстання матросів. Витративши всі запаси палива і харчів, вони вирішили зАатися румунській владі. Зійшли на берег у Румунії і залишилися там як політичні емігранти. Тих, хто повернувся на Батьківщину, бумо заарештовано і страчено.
11 «Герой неокласиків, як і герой акмеїстів і скаманАритів - це активна, енергійна, сильна особистість, героїчна, мужня» $[3$, с. 8$]$.

${ }^{12}$ Аив.: Райбедюк Г. Інтимна мірика Павла Фикиповича [9].

\section{Список використаних Ажерел}

1. Астаф’єв О. Вірш Юрія Клена «Сковорода»: спроба прочитання. Українська мова та література. 1997. Чис. 35.

2. Астаф'єв О. У пошуках світової гармонії (Григорій Сковорода і Юрій Клен: Аіалог через віки). Ніжин : Нiжинський державний пеАагогічний інститут ім. М. ГогоАя, $1996.30 \mathrm{c}$.

3. Вишневська О.А. Рецепція античності у творчості неокласиків, акмеїстів і скамандритів : автореф. Аис. на зАобуття наук, ступеня канА. філол. наук : спец. 10.01.05 «Порівняльне мітературознавство». Тернопіль, 2001. 20 c.

4. Арай-Хмара М. Вибране. Поезії та переклади. Київ, 1969. 302 с.

5. Зварич В. 3. Образ Саломеї у поезї неокласиків. Біблія і культура. 36. наукових сm. Чернівці : Рута, 2000. Вип. 2. С. 50-52.

6. Зеров М. Твори в Авох томах. Поезії. Переклади. Київ : Аніпро, 1990. Т. 1.843 с.
7. Клен Юрій (Освальд Бургардт). Вибране. Київ : Аніпро, 1991. 461 с. : 1 ^. порт.

8. Моренець В. Національні шляхи поетичного моАерну першої половини XX ст. : Україна і Польща. Київ : Основи, 2002. 327 с.

9. Райбедюк Г. Інтимна мірика Павла Филиповича. Слово і час. 1993. № 7. С. 68-72.

10. Рильський М. Зібрання творів у Авадцяти томах. Київ : Наукова Аумка, 1983. Т. 1. 535 с.

11. Рильський М. Зібрання творів у Авадцяти томах. Київ : Наукова думка, 1983. Т. 3. 440 с.

12. Соловей Е. Українська філософська мірика : Навч. посібник. Київ : АибіАь, 1999. 368 с.

13. Стеценко О. Тема кохання у творчості Римьського. Аивослово. 1995. № 10-11.

14. Филипович П. Поезії. Мюнхен : Інститут Аітературознавства при Українському вільному університеті, 1957. $147 \mathrm{c}$.

\section{References}

1. ASTAFIYEV, Oleksandr. 'Skovoroda' Verse by Yuriy Klen: an Attempt of Reading. Ukrainian Language and Literature, 1997, 35, 32-37 [in Ukrainian].

2. ASTAFIYEV, Oleksandr. Searching for World Harmony (Hryhoriy Skovoroda and Yuriy Klen: Dialogue Through the Centuries). Nizhyn: Mykola Hohol Nizhyn State Pedagogical Institute, 1996, 30 pp. [in Ukrainian].

3. VYSHNEVSKA, Oksana. Reception of the Antiquity in the Works of Neoclassics, Acmeists and Skamanders. Extended Abstract of Candidate's Thesis. Ternopil, 2001, 20 pp. [in Ukrainian].

4. DRAI-KHMARA, Mykhailo. Selected Works. Poems and Translations. Kyiv, 1969, 302 pp. [in Ukrainian].

5. ZVARYCH, Vasyl. Salomeya Character in the Neoclassics' Poetry. The Bible and Culture. Collected Scientific Papers. Chernivtsi: Ruta, 2000, iss. 2, pp. 50-52 [in Ukrainian].

6. ZEROV, Mykola. Works in Two Volumes. Poems. Translations. Kyiv: Dnipro, 1990, vol. 1, 843 pp. [in Ukrainian].
7. KLEN, Yuriy (Oswald-Eckard Burghardt). Selected Works. Kyiv: Dnipro, 1991, 461 pp. [in Ukrainian].

8. MORENETS, Volodymyr. National Ways of the Poetical Modern of the First Half of the 20th Century: Ukraine and Poland. Kyiv: Osnovy, 2002, 327 pp. [in Ukrainian].

9. RAIBEDIUK, Halyna. Intimate Lyrics of Pavlo Fylypovych. Word and Time, 1993, 7, 68-72 [in Ukrainian].

10. RYLSKYI, Maksym. Collected Works in Twenty Volumes. Kyiv: Naukova dumka, 1983, vol. 1, 535 pp. [in Ukrainian].

11. RYLSKYI, Maksym. Collected Works in Twenty Volumes. Kyiv: Naukova dumka, 1983, vol. 3, 440 pp. [in Ukrainian].

12. SOLOVEI, Eleonora. Ukrainian Philosophic Lyrics: A Teaching Aid. Kyiv: Lybid, 1999, 368 pp. [in Ukrainian].

13. STETSENKO, Olha. The Theme of Love in Rylskyi Works. Dyvoslovo, 1995, 10-11, 30-34 [in Ukrainian].

14. FYLYPOVYCH, Pavlo. Poems. Munich: Institute for Literary Studies at Ukrainian Free University, 1957, 147 pp. [in Ukrainian]. 


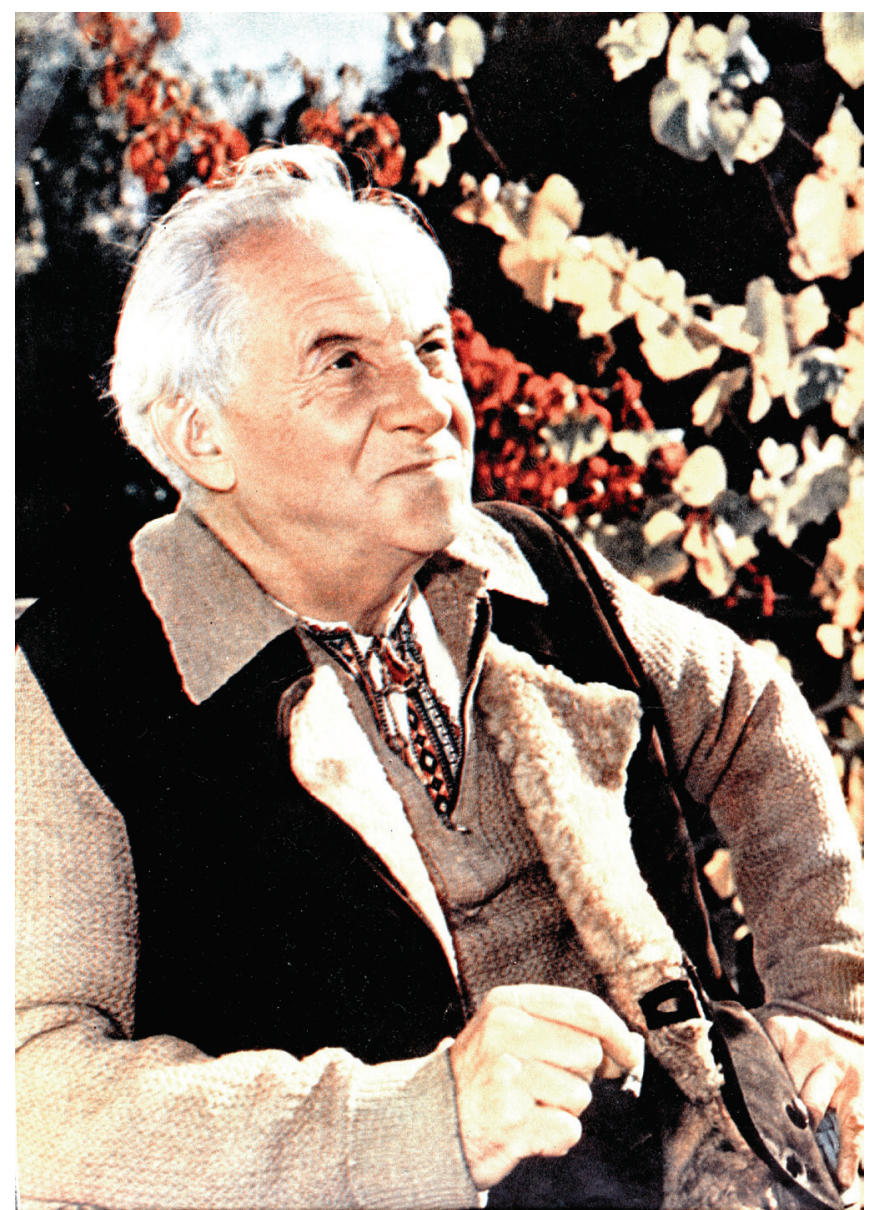

1960-ті рр. Київ. Світлина О. Сланка

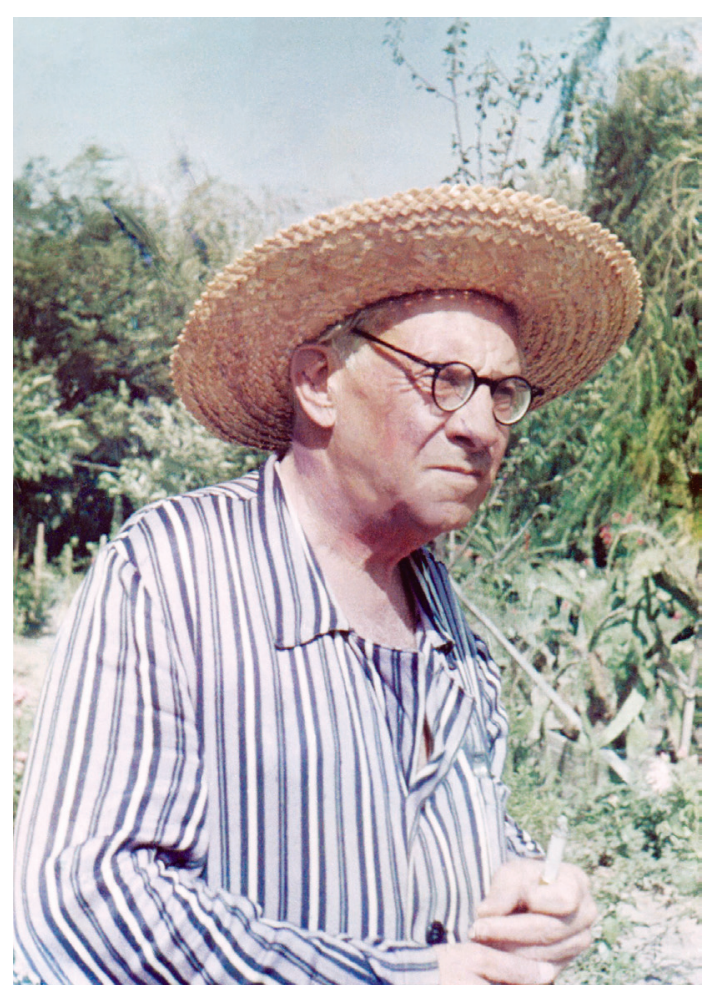

Архів Літературномеморіального музею Максима Рильського (далі- Архів Музею М. Рильського) (MФ-82)
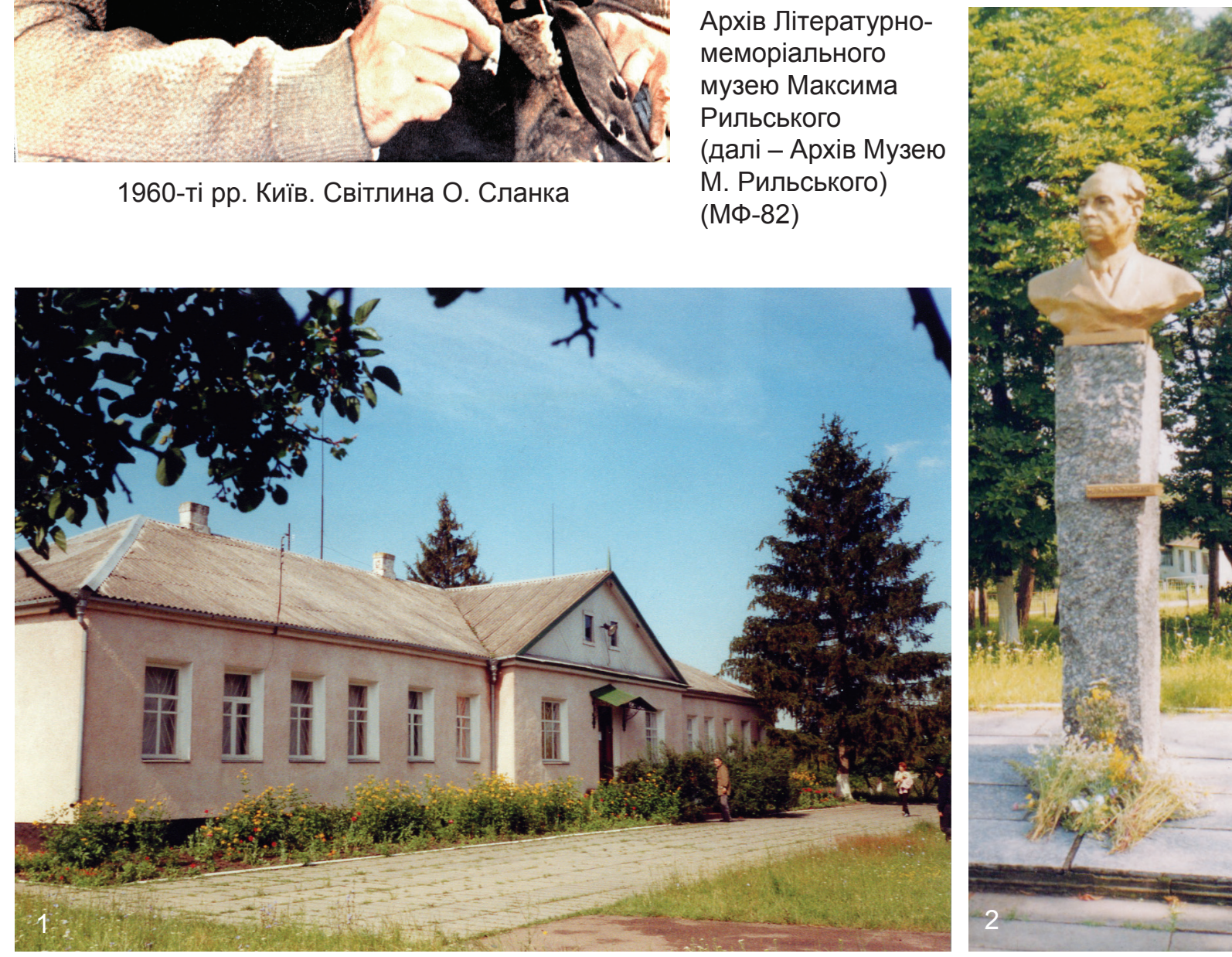

Будинок Рильських (1) та пам'ятник М. Рильському (2). с. Романівка Попільнянського р-ну Житомирської обл. Початок XX ст. Світлини 3. Гудченко (2008) 


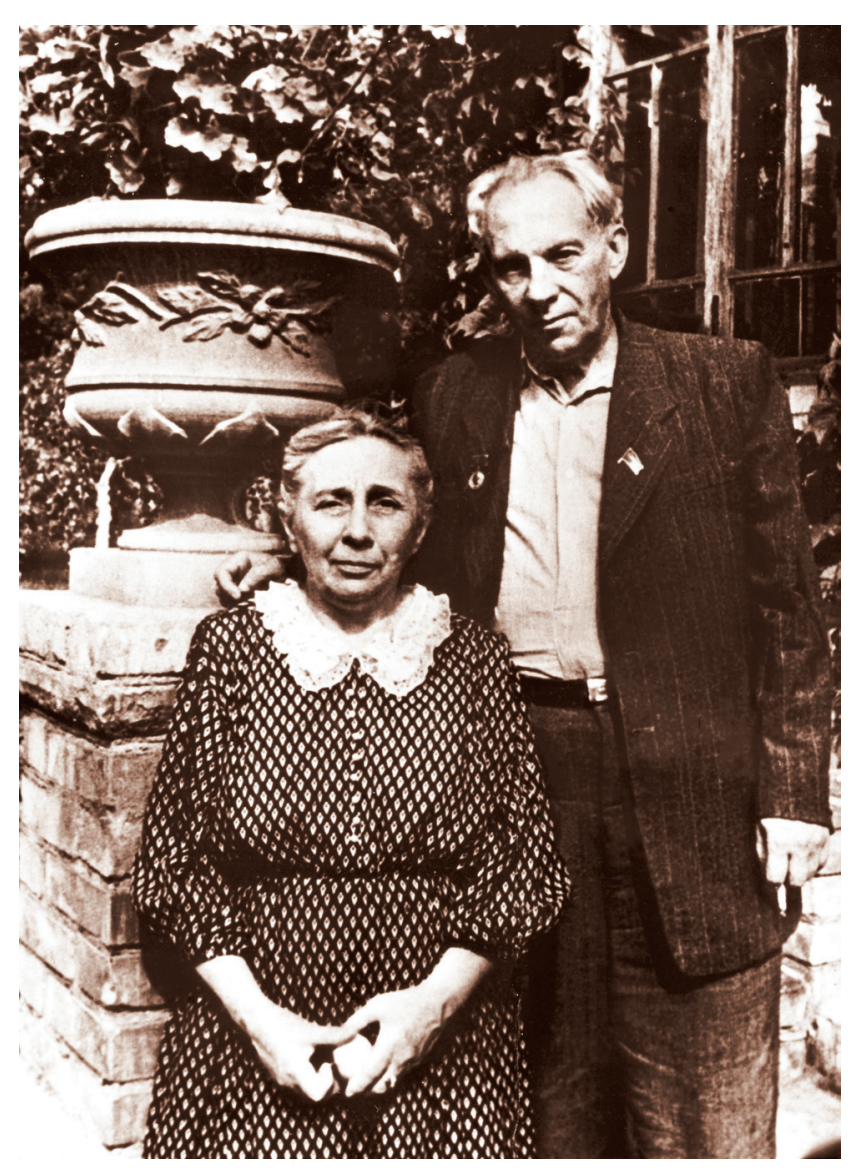

3 дружиною Катериною Миколаївною. Архів ІМФЕ ім. М. Т. Рильського

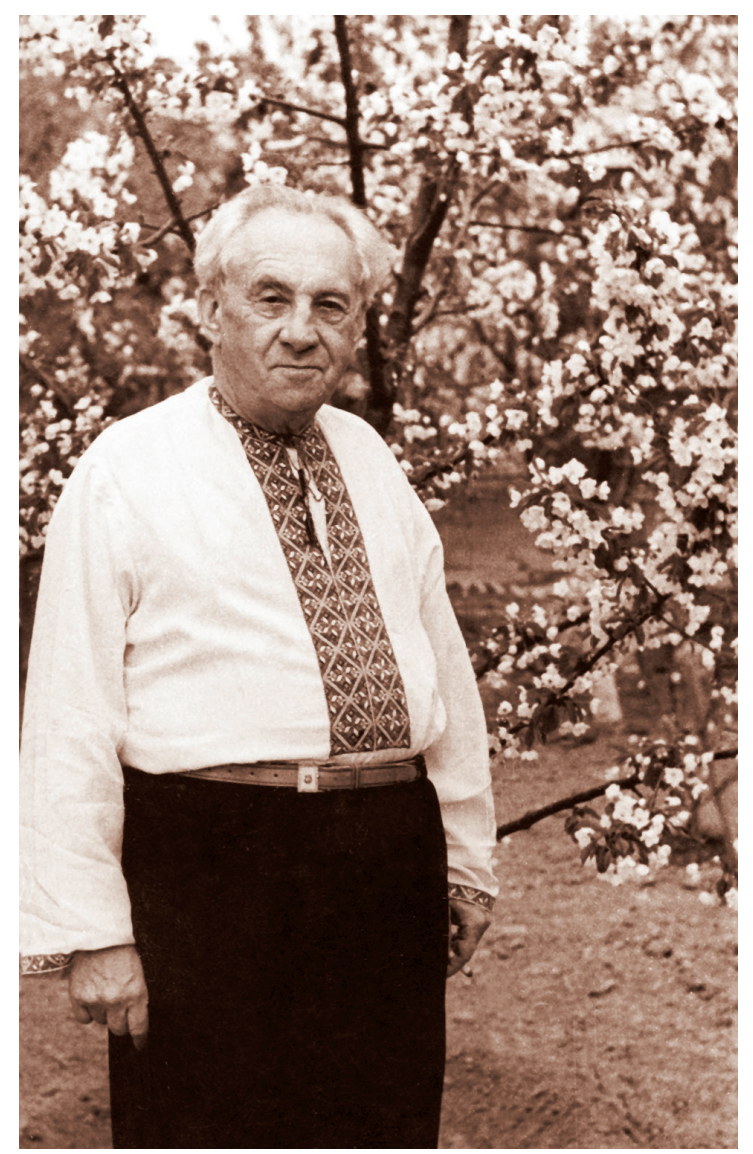

Архів музею М. Рильського (МФ-50)

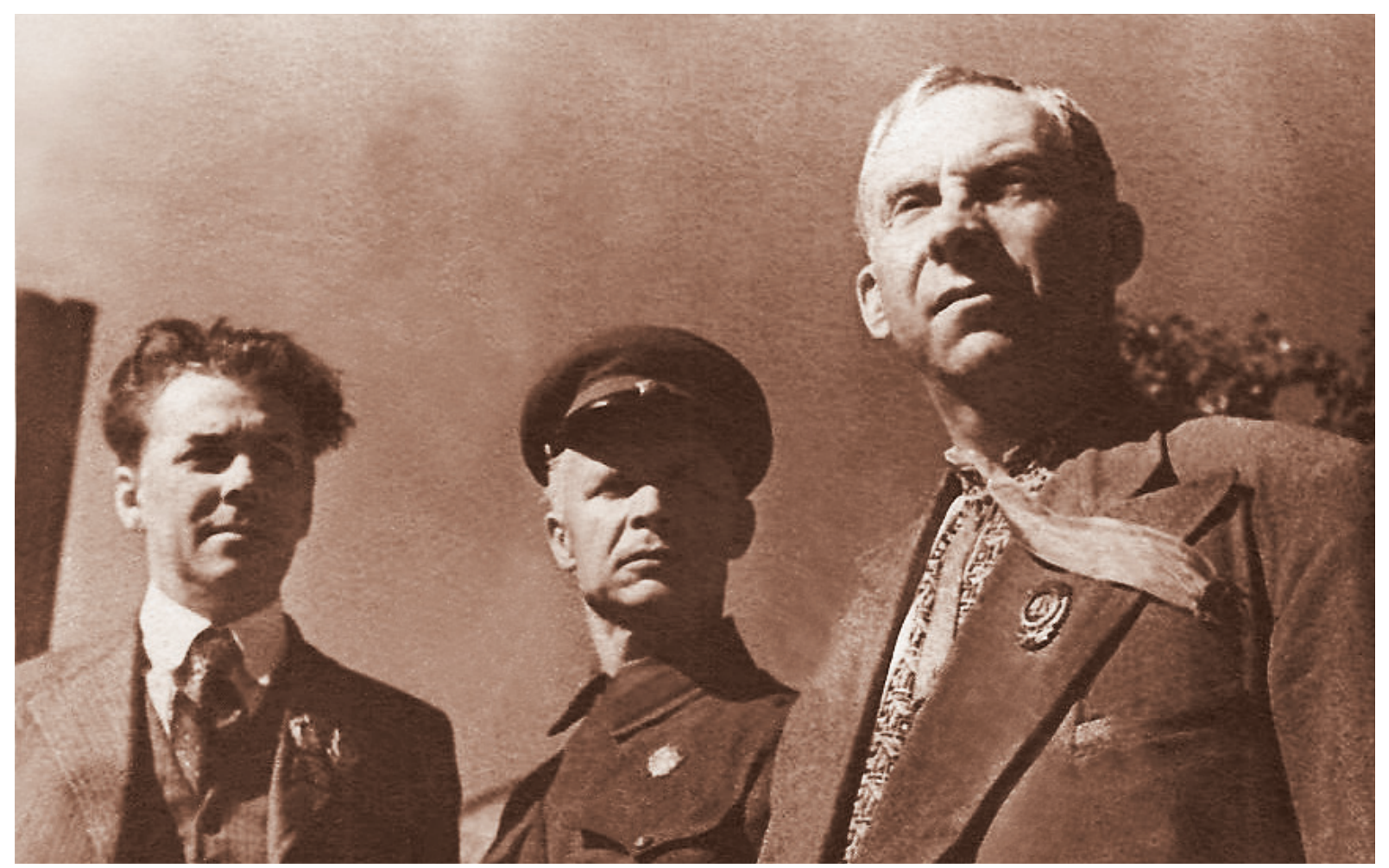

Архів музею М. Рильського

(MФ-275) 


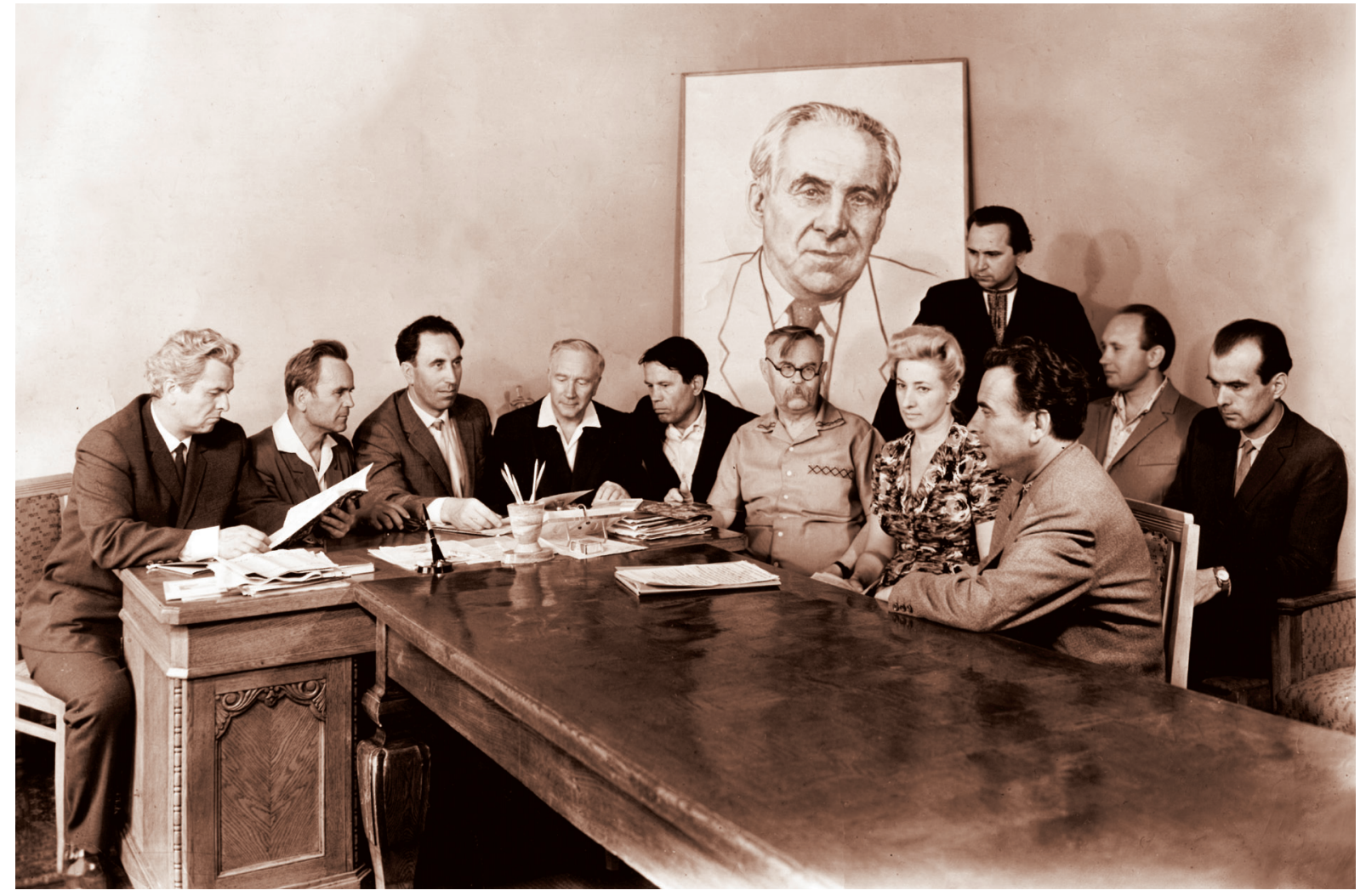

Засідання вченої ради ІМФЕ, присвячене М. Рильському.

Зліва направо: М. Сиваченко, невідомий, О. Дей, Ю. Костюк, М. Гордійчук, К. Гуслистий, Ю. Цвєткова, невідомий; стоять: невідомий, С. Музиченко, І. Власенко

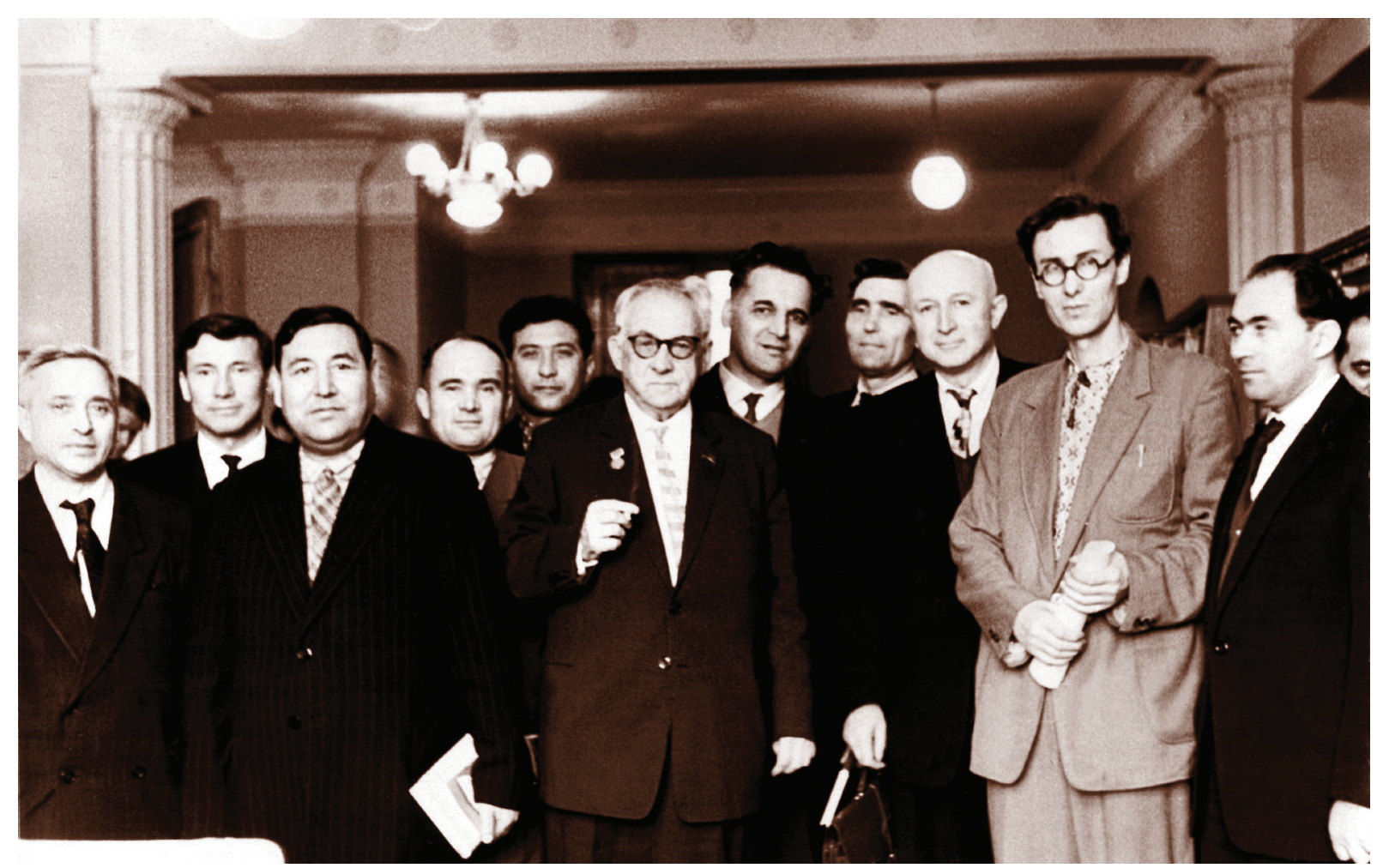

Серед учасників Всесоюзної наради з питань вивчення фольклору. Москва. 3 архіву В. Юзвенко 


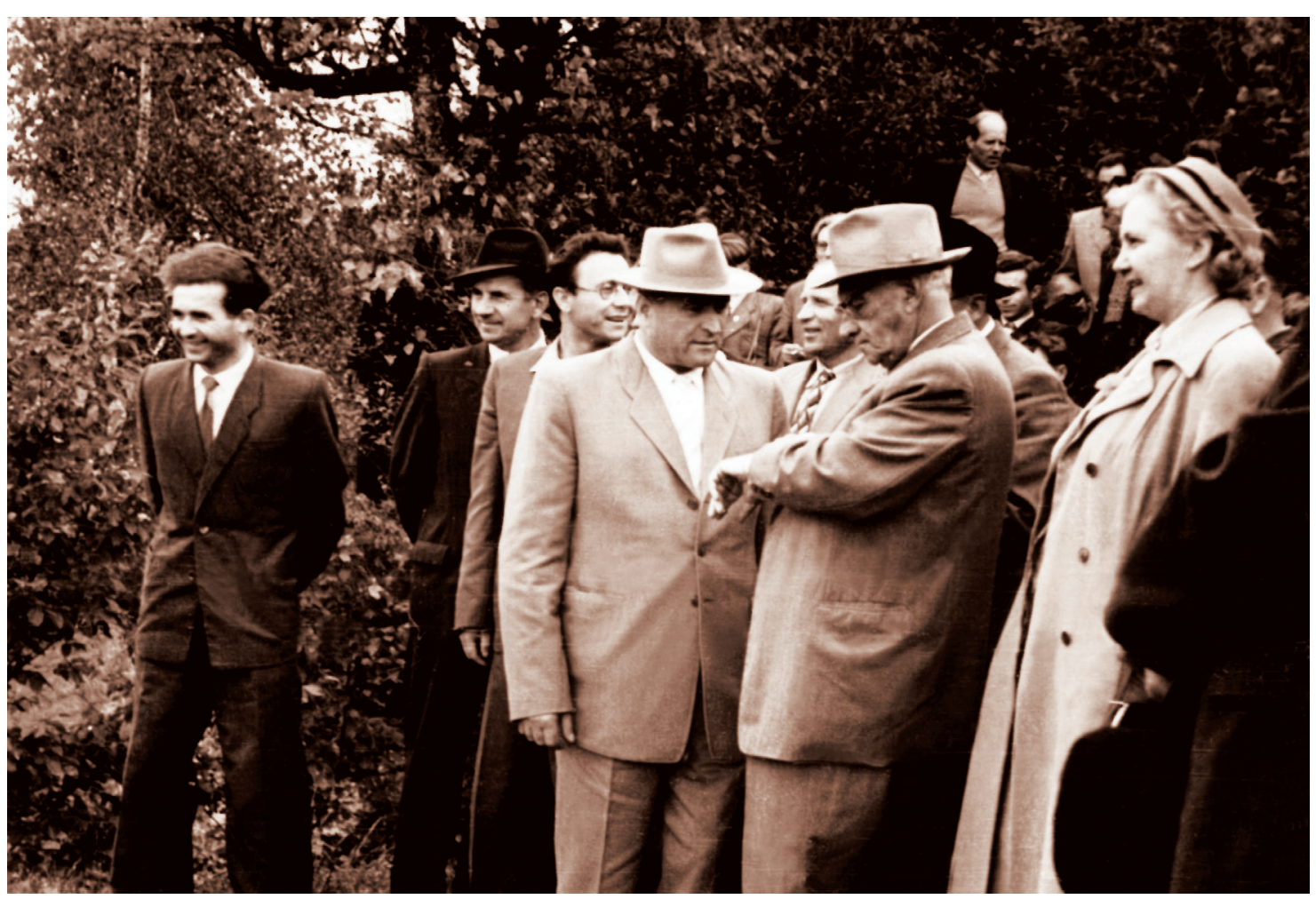

Серед учасників Всесоюзної наукової сесії АН УРСР, присвяченої 150-річчю з дня народження Ю. Словацького. м. Кременець Тернопільської обл. 1953 р.

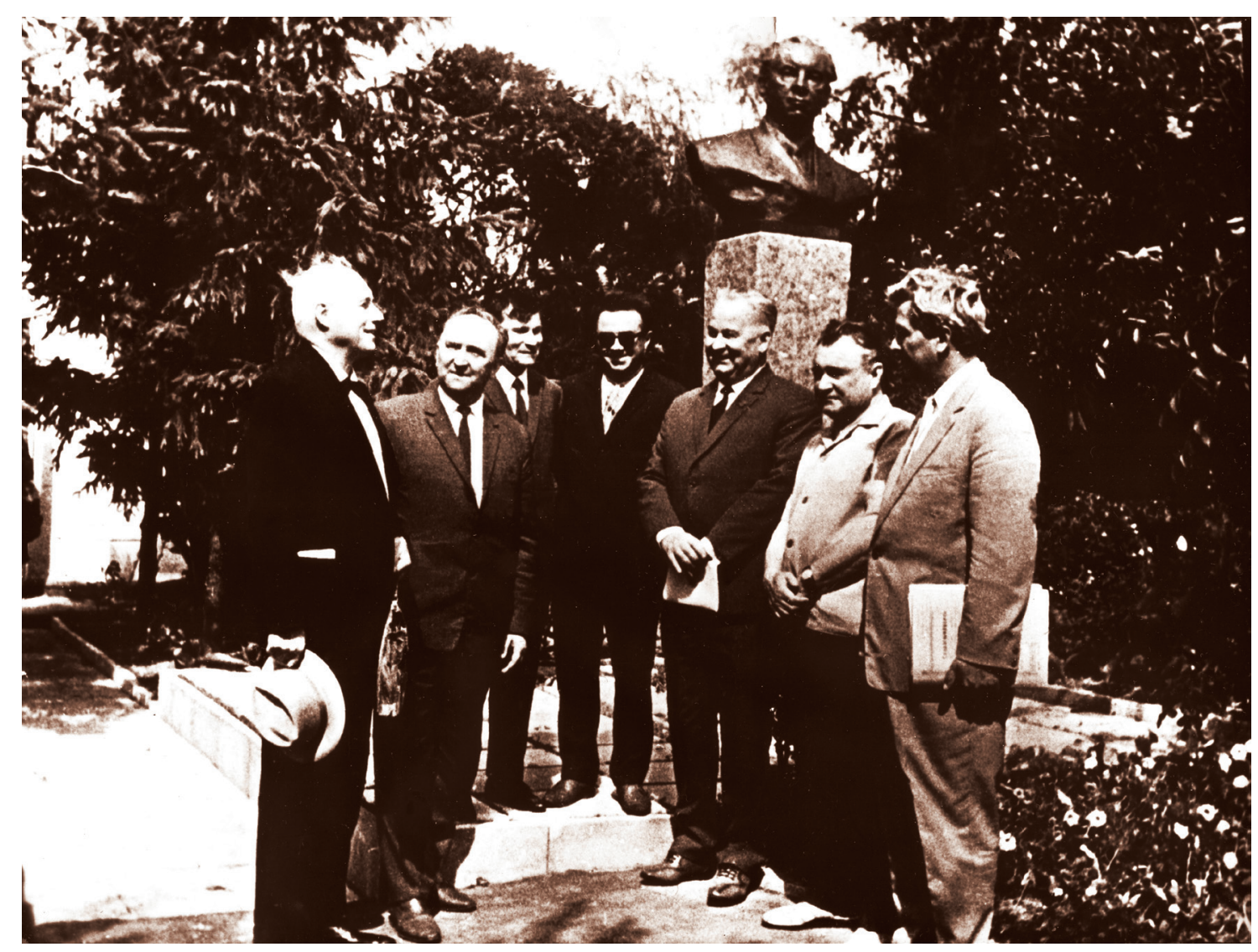

Діячі науки та культури біля пам'ятника М. Рильському. Київ 


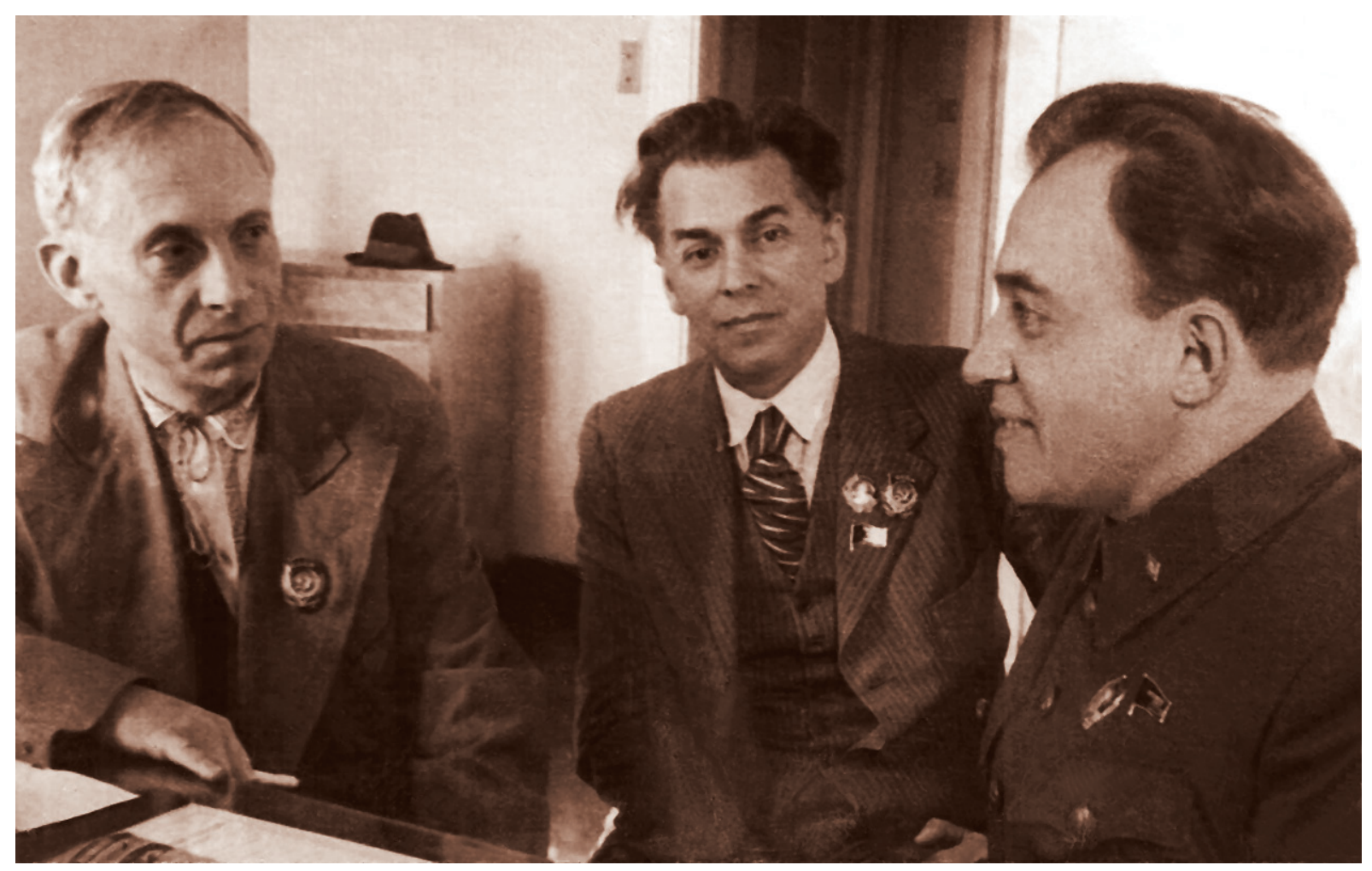

Архів музею М. Рильського (MФ-272)

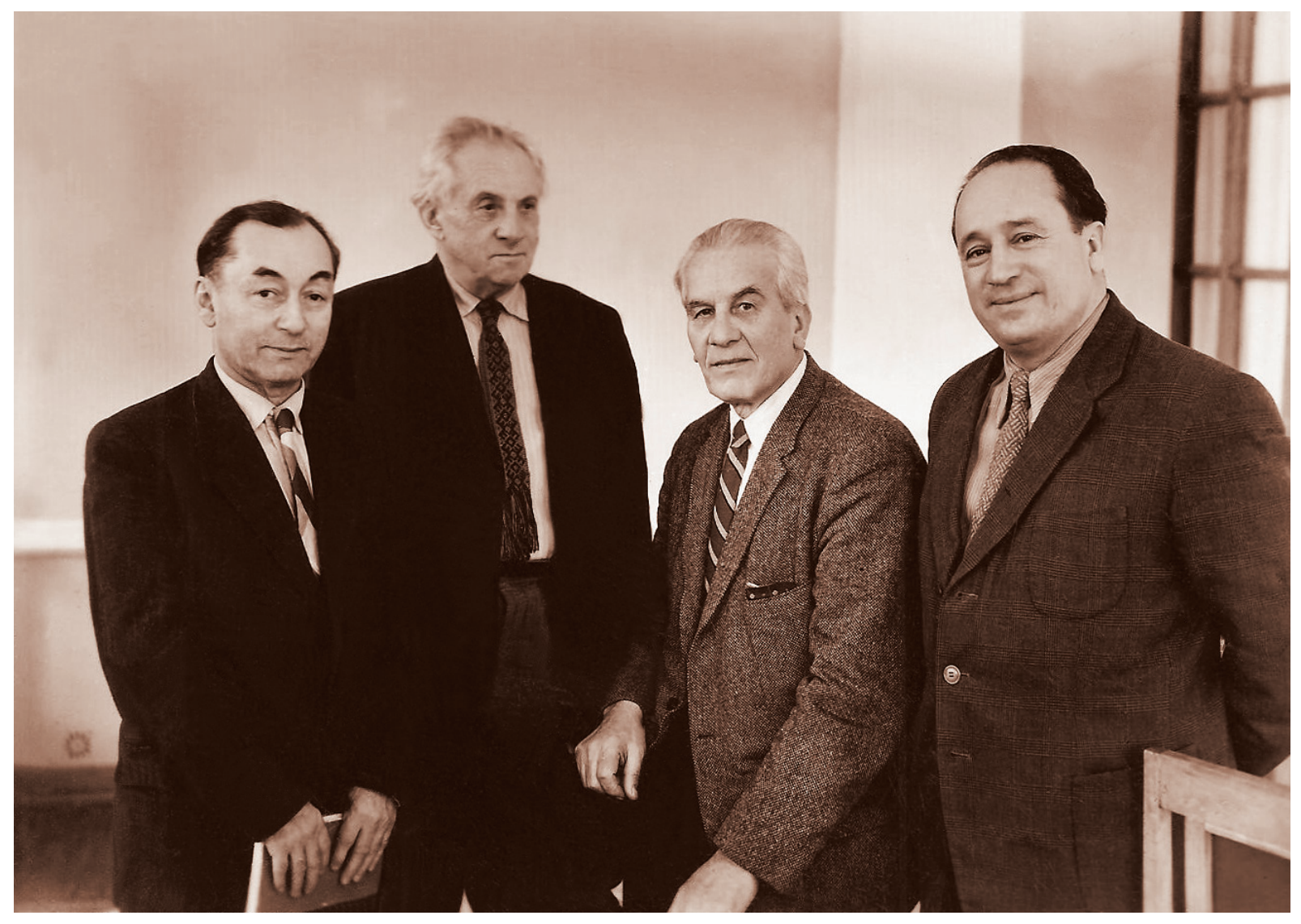

Архів музею М. Рильського

(MФ-387) 




Архів музею М. Рильського

(MФ-376)

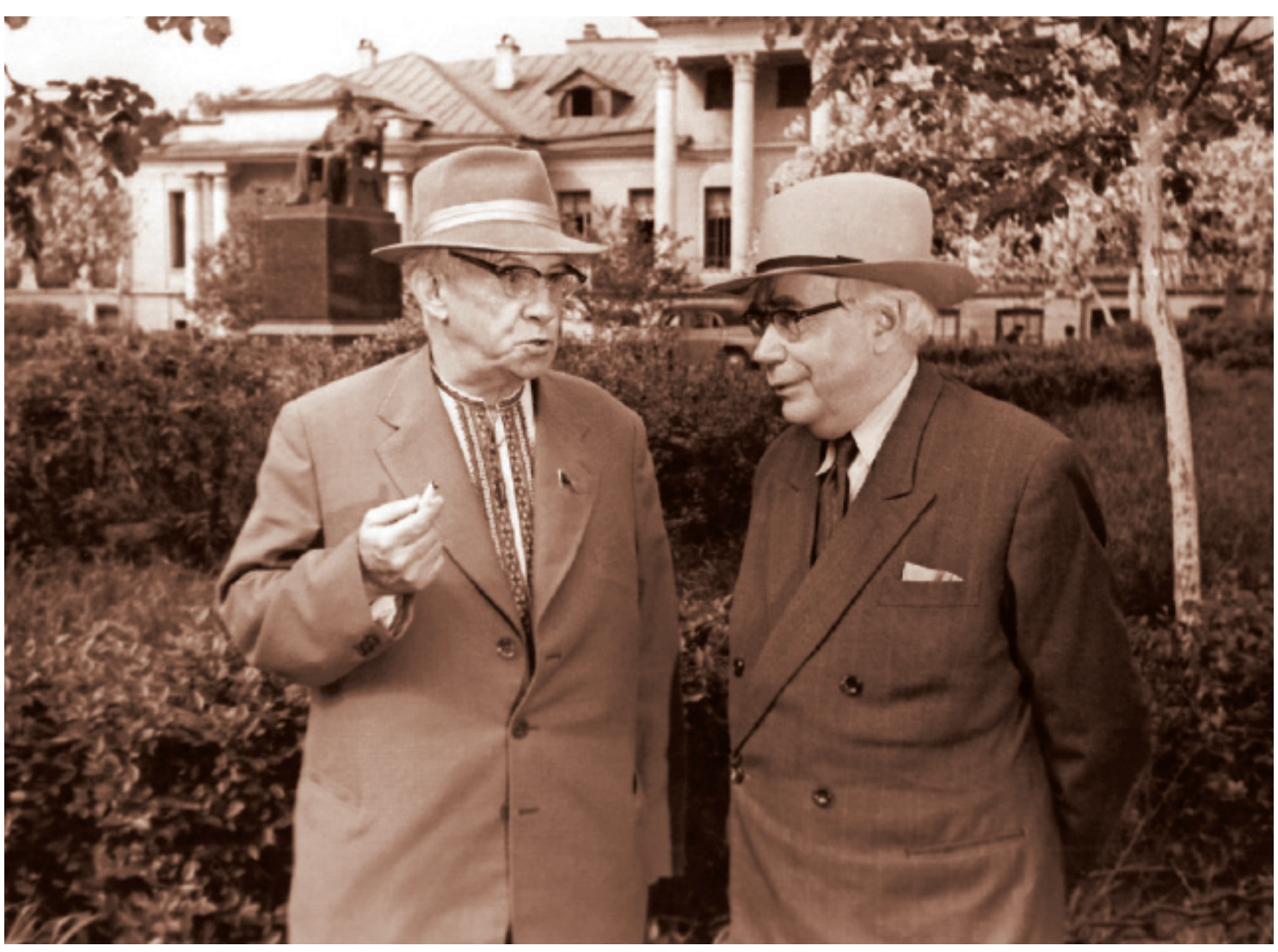

Архів музею М. Рильського

(MФ-1093) 
Архів музею М. Рильського

(MФ-183)

П. Тичина та М. Рильський. Архів музею М. Рильського (MФ-410)
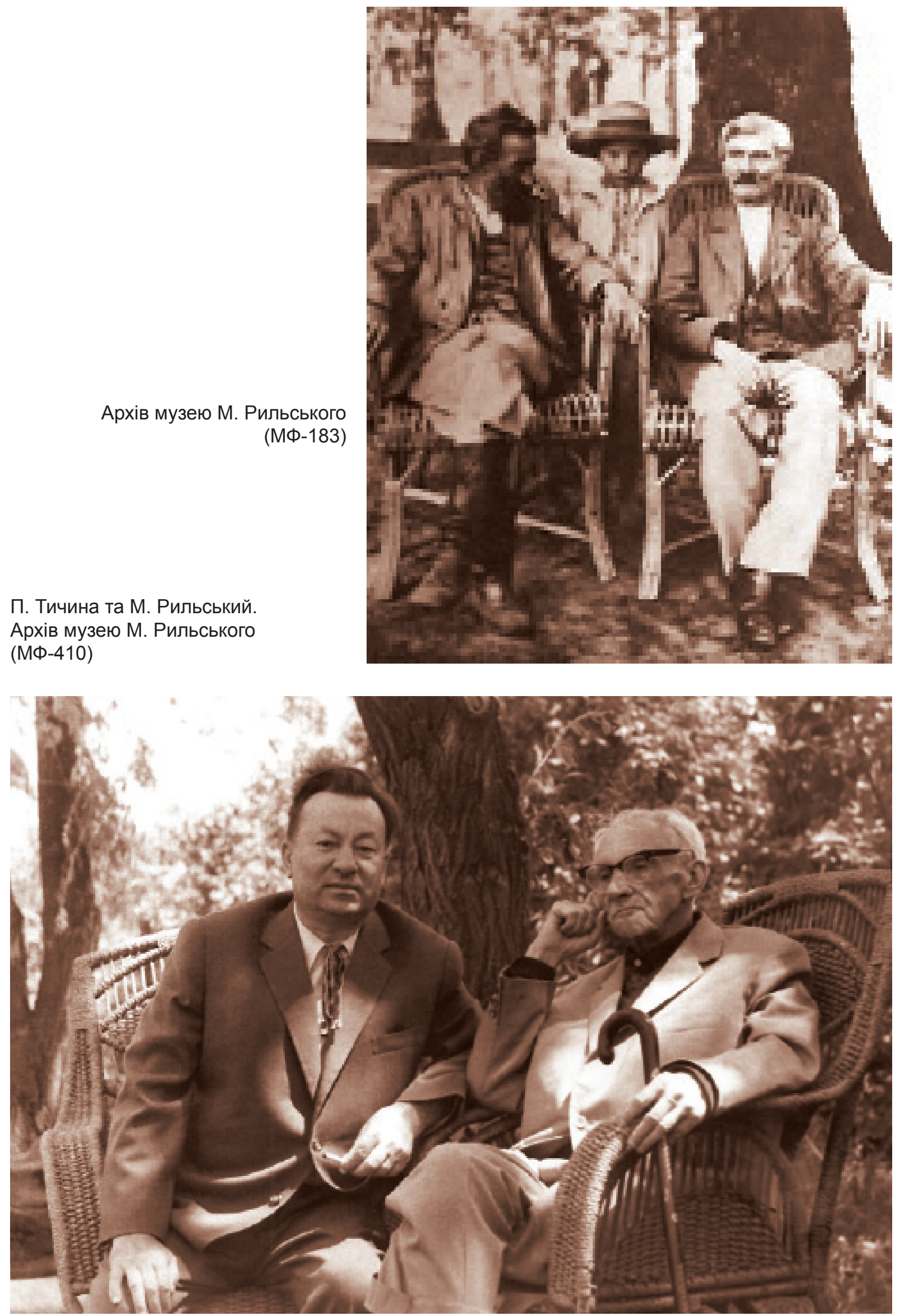

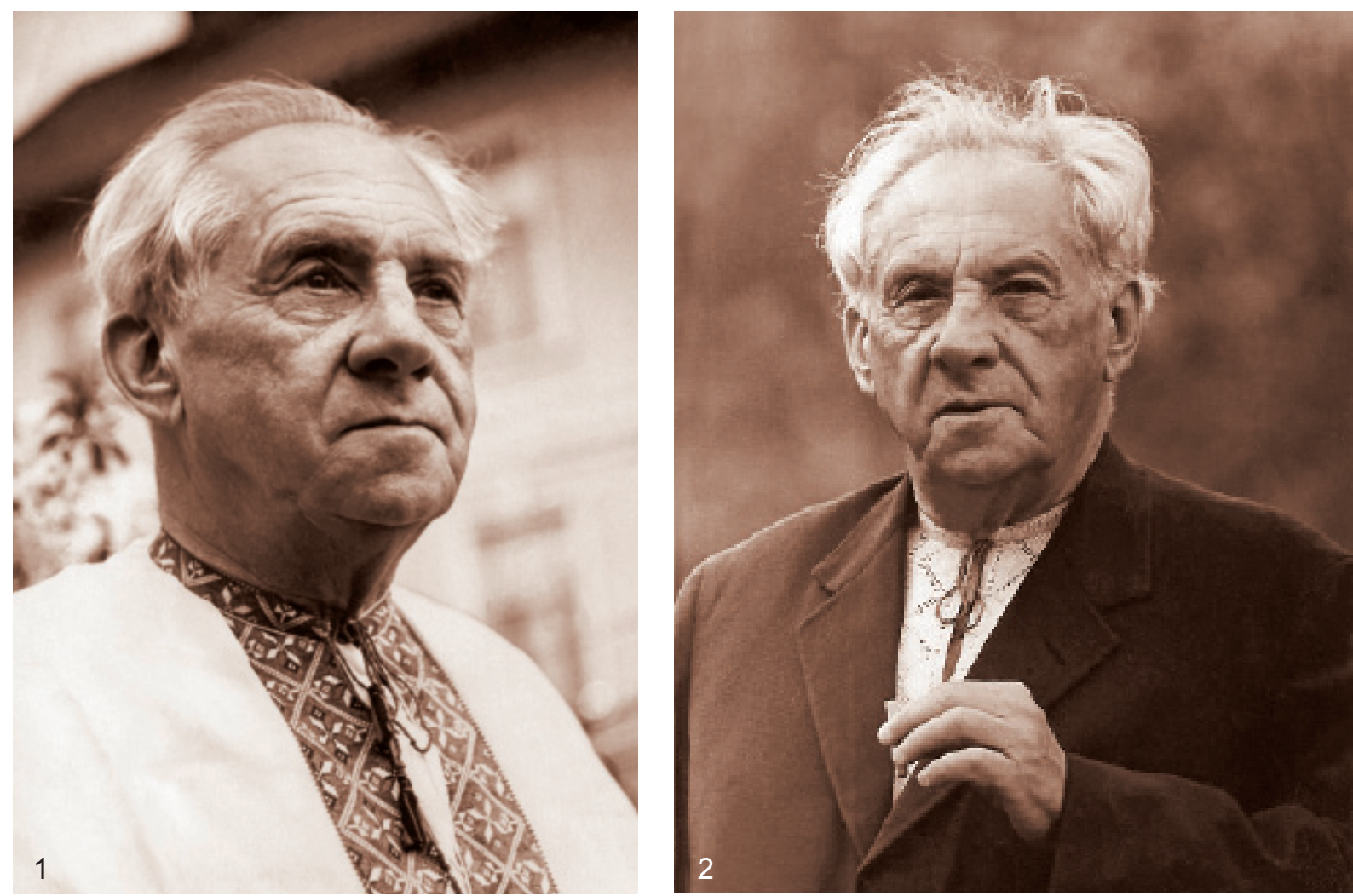

Архів музею М. Рильського

(1 - МФ-53; 2 - МФ-37).

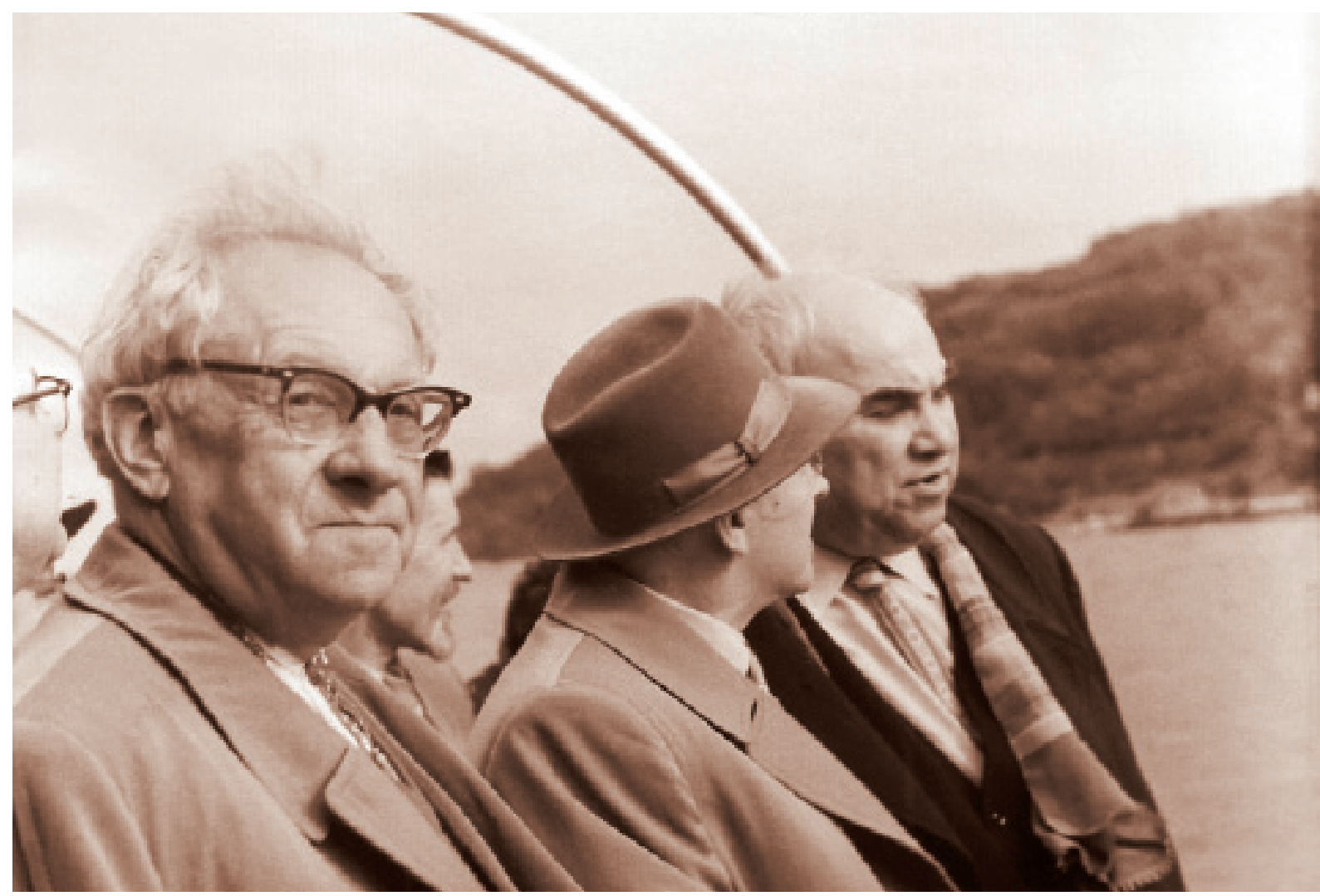

Архів музею М. Рильського

(MФ-407) 


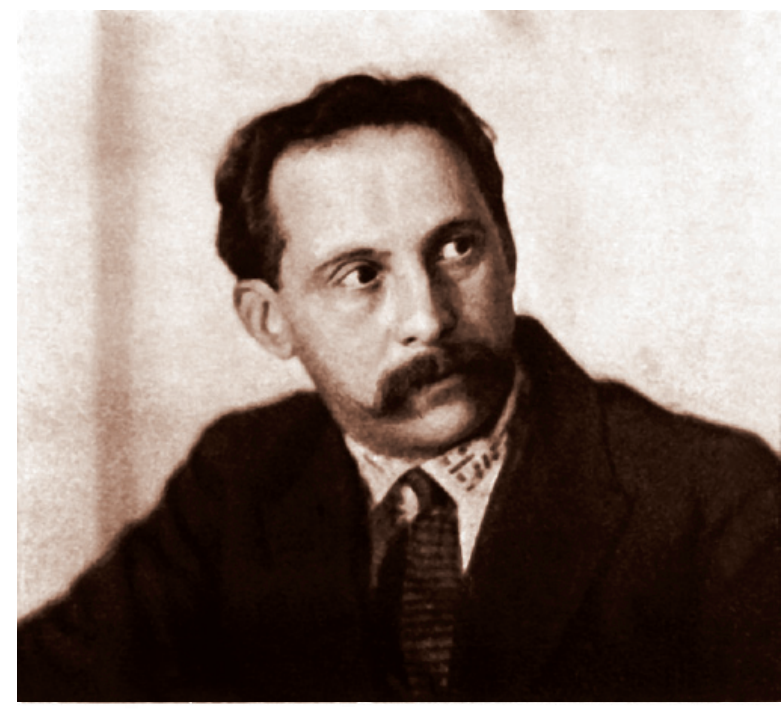

Saxcan Punsionit.

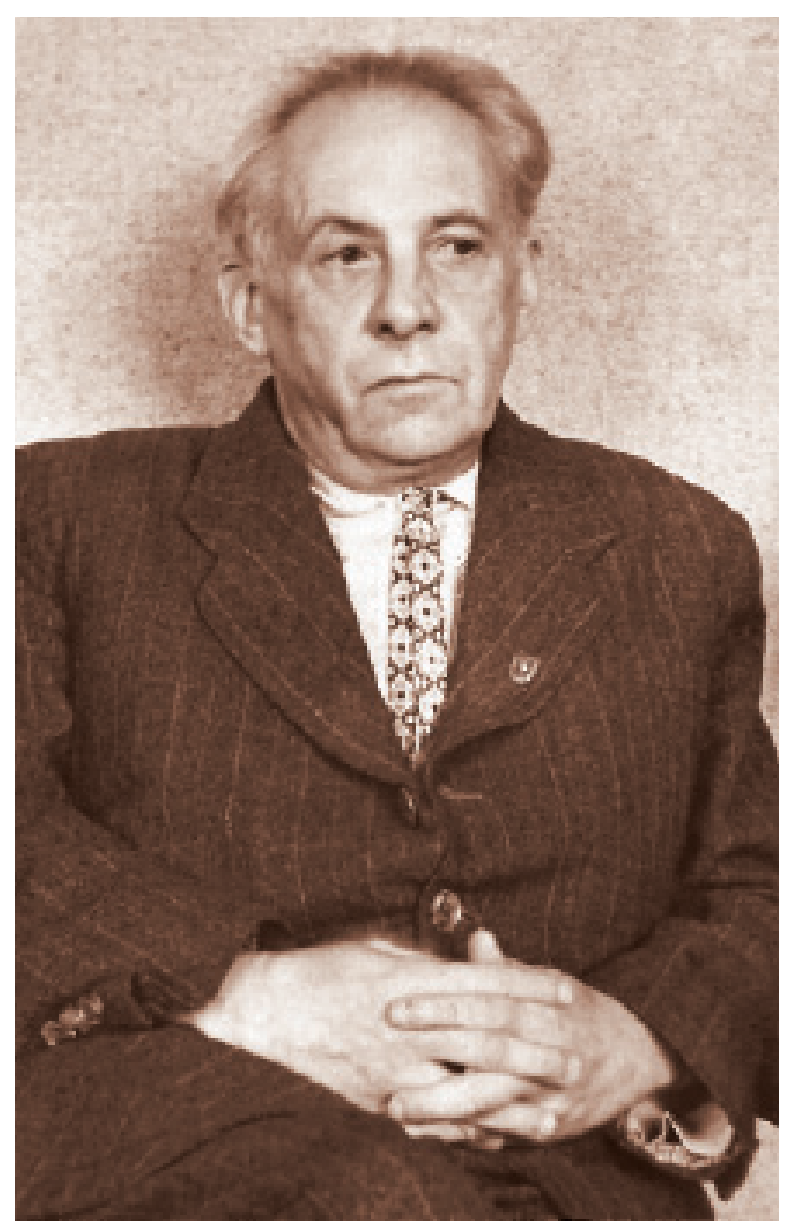

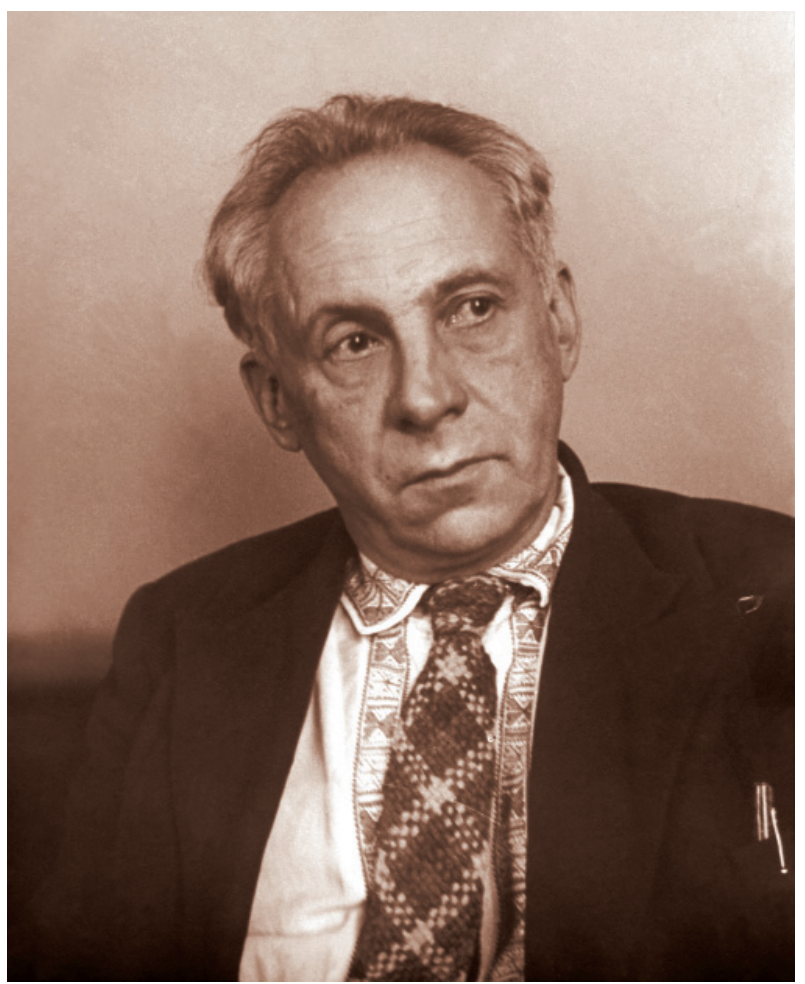

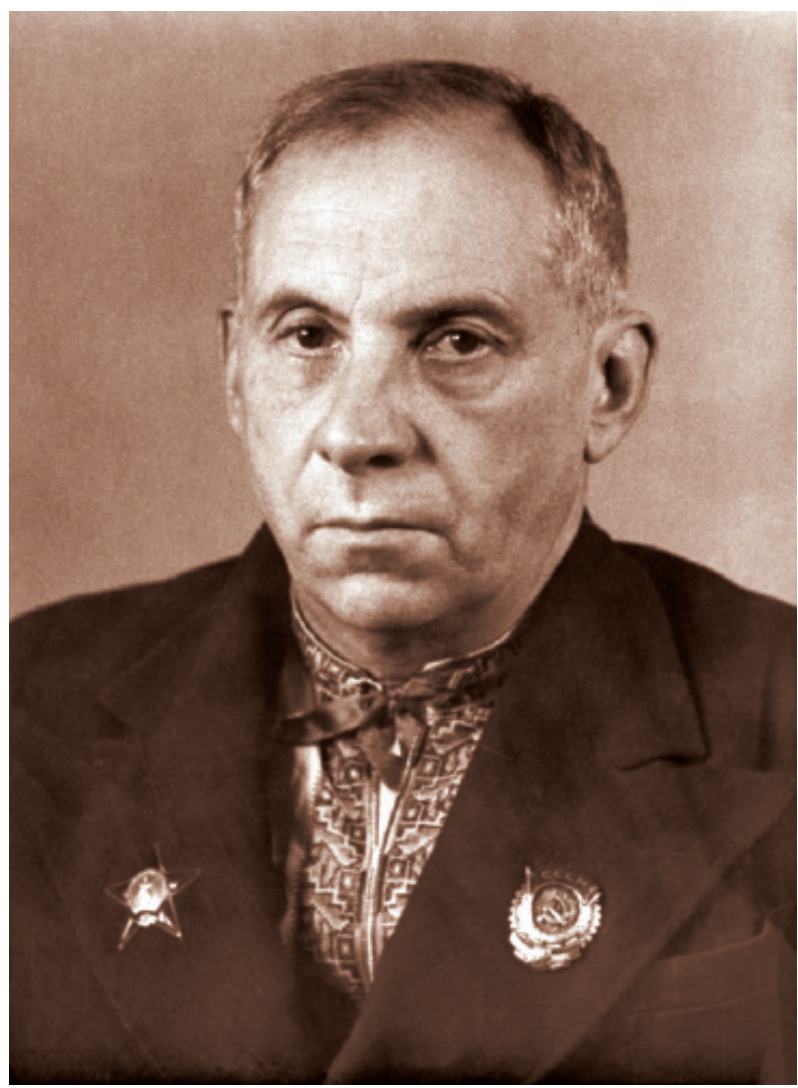

Усі світлини - з Архіву музею М. Рильського 


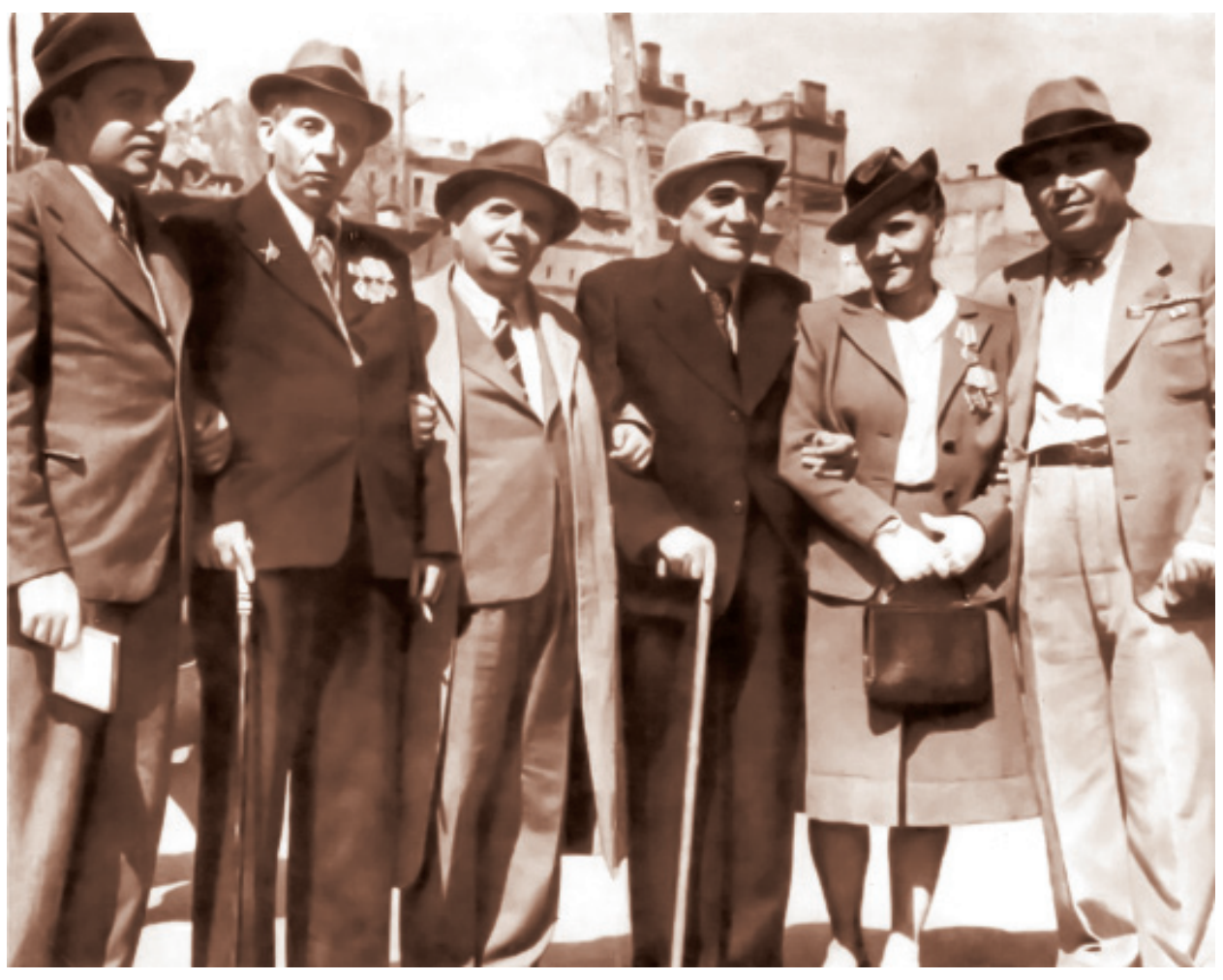

Серед діячів культури.

Зліва направо: О. Корнійчук, М. Рильський, Г. Юра, А. Бучма, Н. Ужвій, І. Паторжинський. Київ. 1946 р.

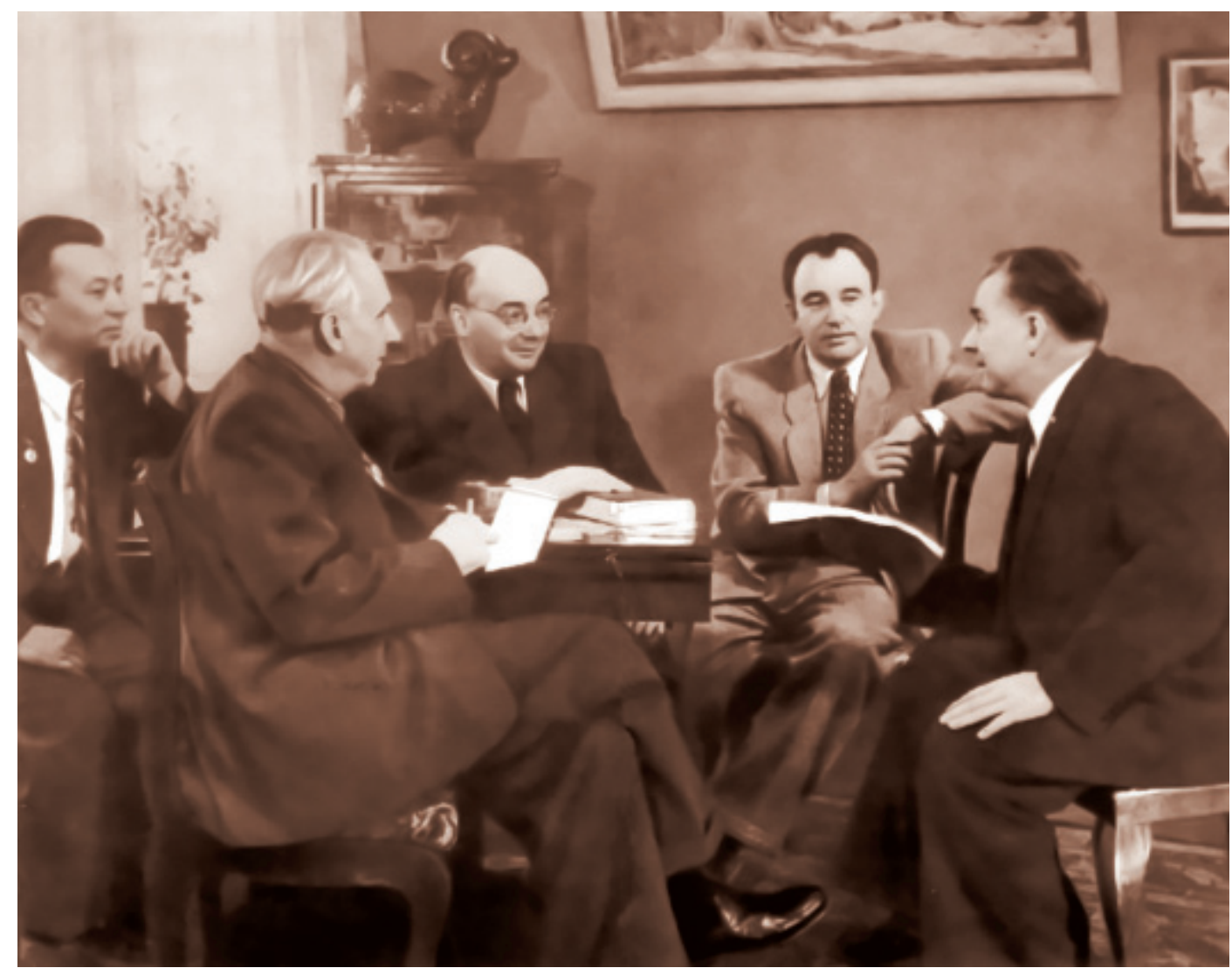

А. Малишко, М. Рильський, М. Бажан, О. Корнійчук, П. Тичина. 1951 р. 


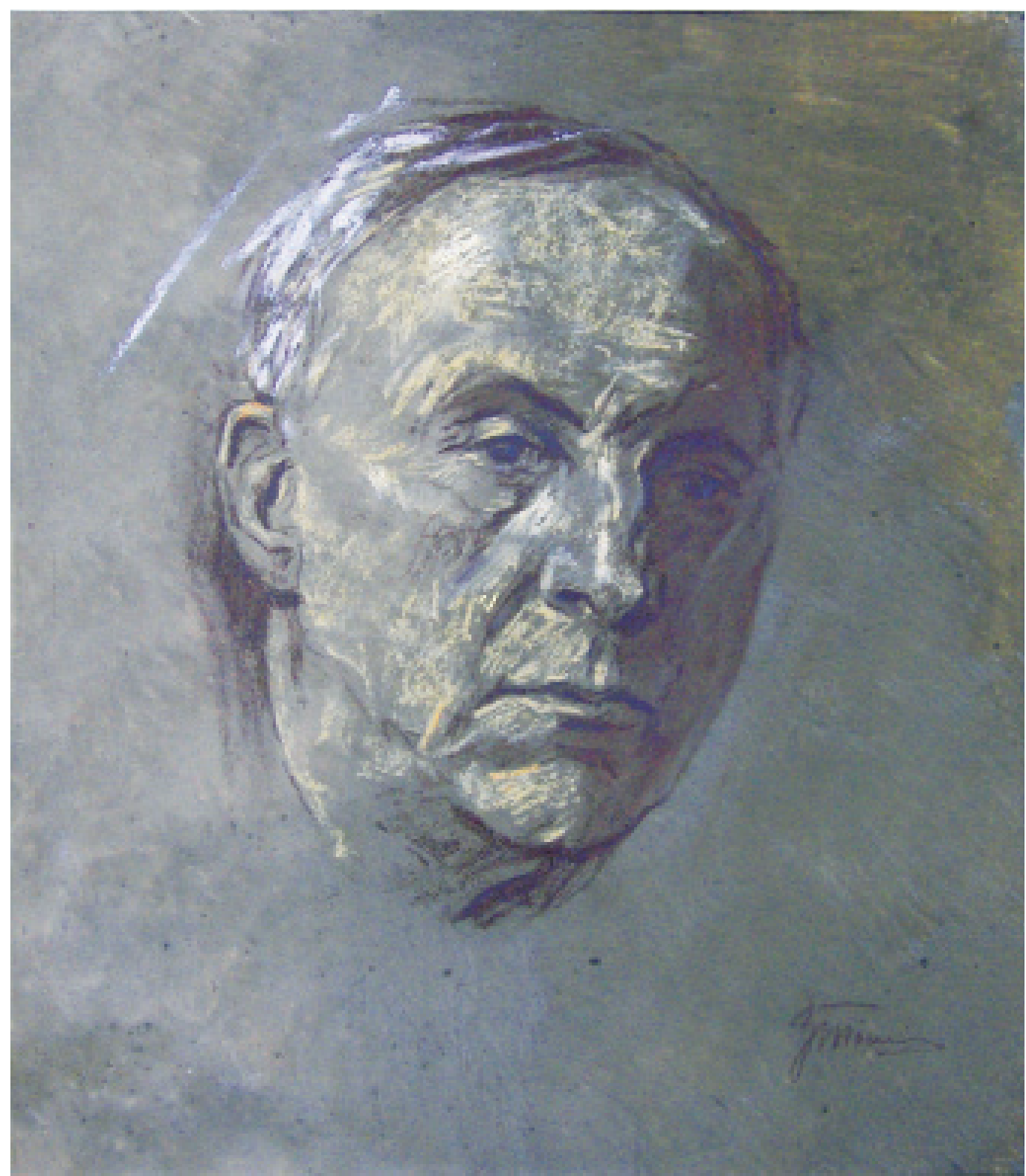

Зиновій Толкачов.

Портрет Максима Рильського. 1949 р. Папір, пастель, гуаш.

Національний художній музей України 